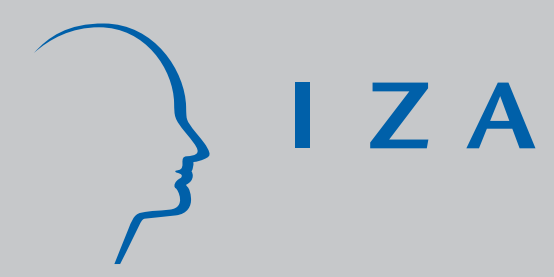

IZA DP No. 1411

Crossing the Tracks? More on Trends in the Training of Male and Female Workers in Great Britain

Melanie K. J ones

Paul L. Latreille

Peter J. Sloane

November 2004 


\title{
Crossing the Tracks? More on Trends in the Training of Male and Female Workers in Great Britain
}

\author{
Melanie K. Jones \\ WELMERC, University of Wales Swansea \\ Paul L. Latreille \\ WELMERC, University of Wales Swansea \\ Peter J. Sloane \\ WELMERC, University of Wales Swansea \\ and IZA Bonn
}

Discussion Paper No. 1411

November 2004

\author{
IZA \\ P.O. Box 7240 \\ 53072 Bonn \\ Germany \\ Phone: +49-228-3894-0 \\ Fax: +49-228-3894-180 \\ Email: iza@iza.org
}

Any opinions expressed here are those of the author(s) and not those of the institute. Research disseminated by IZA may include views on policy, but the institute itself takes no institutional policy positions.

The Institute for the Study of Labor (IZA) in Bonn is a local and virtual international research center and a place of communication between science, politics and business. IZA is an independent nonprofit company supported by Deutsche Post World Net. The center is associated with the University of Bonn and offers a stimulating research environment through its research networks, research support, and visitors and doctoral programs. IZA engages in (i) original and internationally competitive research in all fields of labor economics, (ii) development of policy concepts, and (iii) dissemination of research results and concepts to the interested public.

IZA Discussion Papers often represent preliminary work and are circulated to encourage discussion. Citation of such a paper should account for its provisional character. A revised version may be available directly from the author. 


\section{ABSTRACT \\ Crossing the Tracks? More on Trends in the Training of Male and Female Workers in Great Britain*}

A small number of recent empirical studies for several countries has reported the intriguing finding that the 'advantage' previously enjoyed by men in respect of training incidence and reported in earlier work in the literature has been reversed. The present paper explores the sources of the gender differential in training incidence using Labour Force Survey data, updating previous U.K. studies and providing further insights into the above phenomenon. The results suggest that the greater part of the 'gap' typically relates to differences in characteristics, among which the most important relate to occupation, industry and sector (public/private).

JEL Classification: J1, J2, J7

Keywords: $\quad$ gender, training, decomposition analysis

Corresponding author:

Paul L. Latreille

Department of Economics

University of Wales Swansea

Singleton Park

Swansea, SA2 8PP

United Kingdom

Email: p.I.latreille@swansea.ac.uk

\footnotetext{
* Thanks to participants at the Applied Econometrics Association, Econometrics of Labour Demand conference, in Mons, 7-8 October 2004, for helpful comments on an earlier draft. Material from the Quarterly Labour Force Surveys is Crown Copyright, has been made available from the Office for National Statistics (ONS) through the UK Data Archive and has been used by permission. Funding from the European Social Fund is gratefully acknowledged. None of these organisations bears any responsibility for the analysis or interpretation of the data reported here.
} 


\section{Introduction}

Standard economic (human capital) theory predicts that the incidence of training should be higher among men than women, and this has largely been confirmed in empirical studies ${ }^{1}$. Recently however, a small number of studies have reported the intriguing finding that the 'advantage' previously enjoyed by men and reported in the earlier work in the literature may have been reversed and that women are now more likely to participate in training than their male counterparts. Moreover, this phenomenon is not confined to a single country, but has been identified in the U.K. (inter alia Greenhalgh and Mavrotas, 1994, 1996; Gibbins, 1994; Dearden et al., 1997; Green and Zanchi, 1997; Shields, 1998), Australia (Miller, 1994; Wooden and VandenHeuvel, 1997) and the U.S. (Simpson and Stroh, 2002). Most recently, Arulampalam et al. (2003) report that on the basis of the European Community Household Panel (ECHP) 1994-99, among 25-54 year olds, women are substantially more likely to start training in a given year in Denmark, Finland, Italy and Spain ${ }^{2}$. In the U.K., this phenomenon was first explicitly recognised by Greenhalgh and Mavrotas (1994) and by Gibbins (1994), albeit the differentials at the time to which their data relate were small ${ }^{3}$. As Figure 1 indicates however, a clear, long-term trend is in evidence, with the gap having widened substantially since the period covered by the last published study focusing on that economy $(1994 / 5)$.

The reasons for this phenomenon are however unclear, and several, mutually admissible factors have been proposed in the literature. Green and Zanchi (1997) and Wooden and

\footnotetext{
${ }^{1}$ For the U.K. for example, see Greenhalgh and Stewart, 1987; Booth, 1991, 1993; Green, 1991, 1993, 1994.

${ }^{2}$ Small but positive differentials in favour of women are also found for the Netherlands, Ireland, France and Britain. In the case of Britain, the smaller differential compared to the data reported in the present paper presumably reflects sample, definitional and measurement differences between the surveys deployed.

${ }^{3}$ Shields (1998) indicates that the phenomenon has existed in the U.K. since the mid-1980s in respect of employer-sponsored training for full-time employees. He goes on to suggest (p. 189) that determinants that remain contentious are whether "male employees receive more training than equivalent females, whether firms in technology-led industries fund more training, whether public sector employees receive more training than private sector workers, and whether the incidence of training moves pro-cyclically."
} 
VandenHeuvel (1997) for example, suggest that it may be a corollary of wider legal, institutional and social changes reflected/resulting in improvements in the labour market status of women. As Simpson and Stroh (2002: 25) argue however:

"greater employment equality between men and women should have contributed to a reduction in the training gap. Instead, at least for...[the U.K. and Australia], we have evidence that women were more likely to receive training than men.

One possibility of course, is that increased labour force participation rates among women may give rise to a statistical '(re-)entrants' effect, whereby training incidence is higher among those returning to the labour market following interruptions to their work histories, for example due to childcare and other family responsibilities (Green, 1991; Green and Zanchi, 1997). Relatedly, the increased payback period afforded by the tendency for later childbirth (Dex et al., 1996: 67) may also have contributed to the rise in female participation in training ${ }^{4}$. This logic could be used to explain both an increased supply of training by employers, and also an increased demand for training by female employees (which is itself a candidate explanation).

An alternative set of explanations revolves around the possibility that women possess 'advantages' in terms of particular characteristics associated with higher training incidence, including superior endowments (qualifications) that (primarily younger) females bring to the labour market and occupational composition. The former has been deployed to justify part of the trend towards more female participation in 'external' training in Australia by Wooden and VandenHeuvel (1997).

\footnotetext{
${ }^{4}$ Thanks are due to Julie Latreille for this observation. Dex et al. also document that among those who left employment (i.e. who did not or could not benefit from Statutory Maternity Leave (first introduced in 1976)), there has been a tendency for an earlier return to the labour market, and a greater likelihood of returning between births. Both of these factors are likely to raise the returns to training for the individual.
} 
Figure 1: Percentage of employees receiving work-related education and training in the last 4 weeks

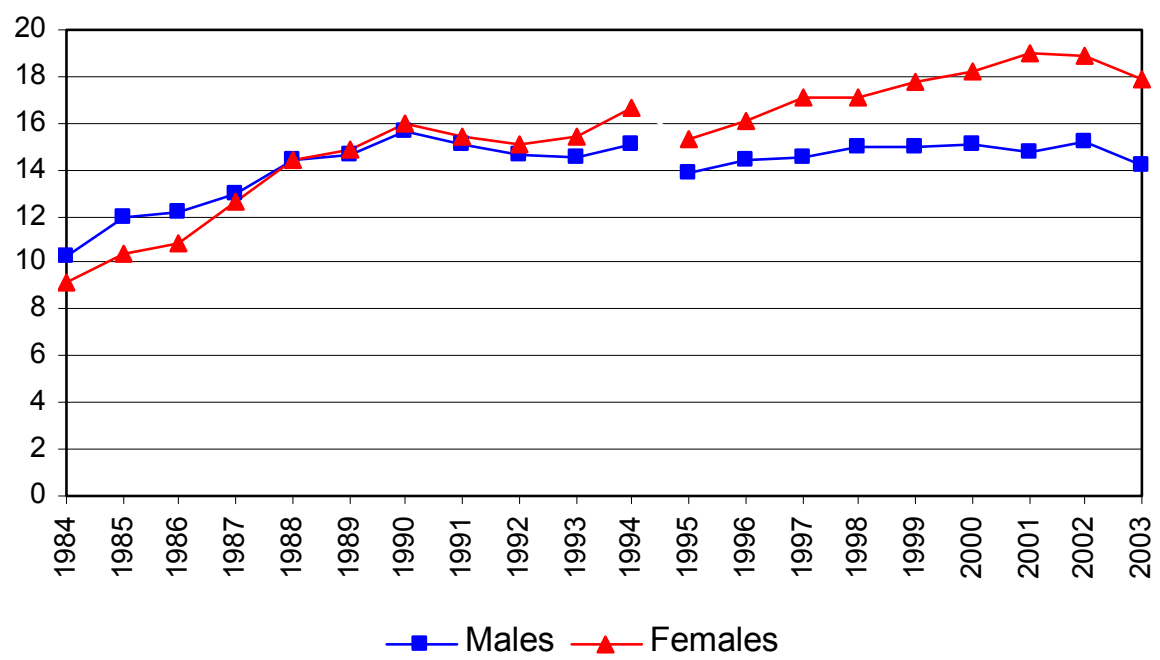

Notes: Working age persons only (16-64 and 16-59 for males and females respectively) in Great Britain. Job-related training refers to education or training connected with the respondent's job. Data are weighted. The discontinuity between 1994 and 1995 resulted from a change in questionnaire design. From 1995 only those who reported receiving training in the 13 weeks preceding the survey were asked whether they had received any training during the last 4 weeks.

Source: Authors' calculations based on Labour Force Survey 1984-91 and Quarterly Labour Force Survey (Spring quarter) from 1992.

Simpson and Stroh (2002) in contrast, argue that technological/labour demand changes by employers coinciding with occupational segregation by gender explain much of the training differential in favour of women. These authors maintain that the increased training participation by females is largely a consequence of technological changes such as the introduction of computers that have primarily affected female-intensive occupations in the 1990s. Using U.S. data, they report that around one-third of the gender difference in overall training incidence can be attributed to occupational differences, rising to 40 per cent for employer-supported training. While occupational factors are clearly crucial however, these do not on their own explain the entirety of the gender differential. Moreover, while the underlying role of technological change as a determinant of training incidence is compelling, 
it is perhaps difficult to envisage that this factor alone has given rise to the longer-term pattern and widening divergence evident for most of the period in Figure $1^{5}$.

More recent work on training has been based on the imperfect competition model proposed by Acemoglu and Pischke (1998, 1999a and 1999b), which suggests that the monopsonistic power of the employer will decline as the probability of re-employment increases. Labour markets which are denser in geographic terms will have better matching opportunities and a greater likelihood of poaching, thus making training more general and less profitable for the employer. At the same time, where monopsony power is greater, workers will be paid less than their full marginal product, turning general skills into de facto specific skills. This form of wage compression will increase labour market rents and make training more profitable for employers. Wage compression may result from the presence of transactions costs in the labour market, making it costly for workers to change employers, or from asymmetric information between current and prospective employers about the abilities and performance of workers and the impact of institutions such as trade unions. One example is the minimum wage, which increases the pay of less skilled workers, while leaving the pay of more skilled workers largely unaffected. This will have a larger impact upon women than upon men.

Two recent studies have tested some of these propositions, using British data. First, Brunello and Gambarotto (2004), using the ECHP, examined whether local labour market density influenced the amount of employer-provided training. In line with the theory, they found a significant negative effect of density across the UK when evaluated at the average firm size in the local area over the period 1994 to 2000. Second, Almeida-Santos and Mumford (2004), using WERS 1998 matched employer-employee data, found that higher levels of

\footnotetext{
${ }^{5}$ A further alternative rejected by Wooden and VandenHeuvel (1997) in the absence of any plausible rationale for systematic gender differences is the economic cycle. The fact that the phenomenon exists across economies at different times, together with the clear trend in Figure 1, unambiguously implies a secular change.
} 
wage compression (measured in absolute or relative terms) were positively related to training incidence and duration. They also found that women were not significantly more or less likely to receive training than men, but that the duration of training spells was significantly shorter for women than for men.

As previous studies make clear, it is important to distinguish among different types of training. Significant among these is a move to more on-the-job training, as shown in Figure 2, which may be more convenient for certain groups (most notably females and part-time employees), thereby improving access. However, as Figure 2 makes clear, whereas participation in either on-the-job or off-the-job was broadly similar for men and women in 1992, the differential is in fact wider and growing for off-the-job training. While the growth in on-the-job training may, therefore, have offered expanded training opportunities for some women, changes in the type of training also fail to tell the whole story.

\section{Figure 2: Percentage of employees receiving specific types of training in the last 4 weeks}

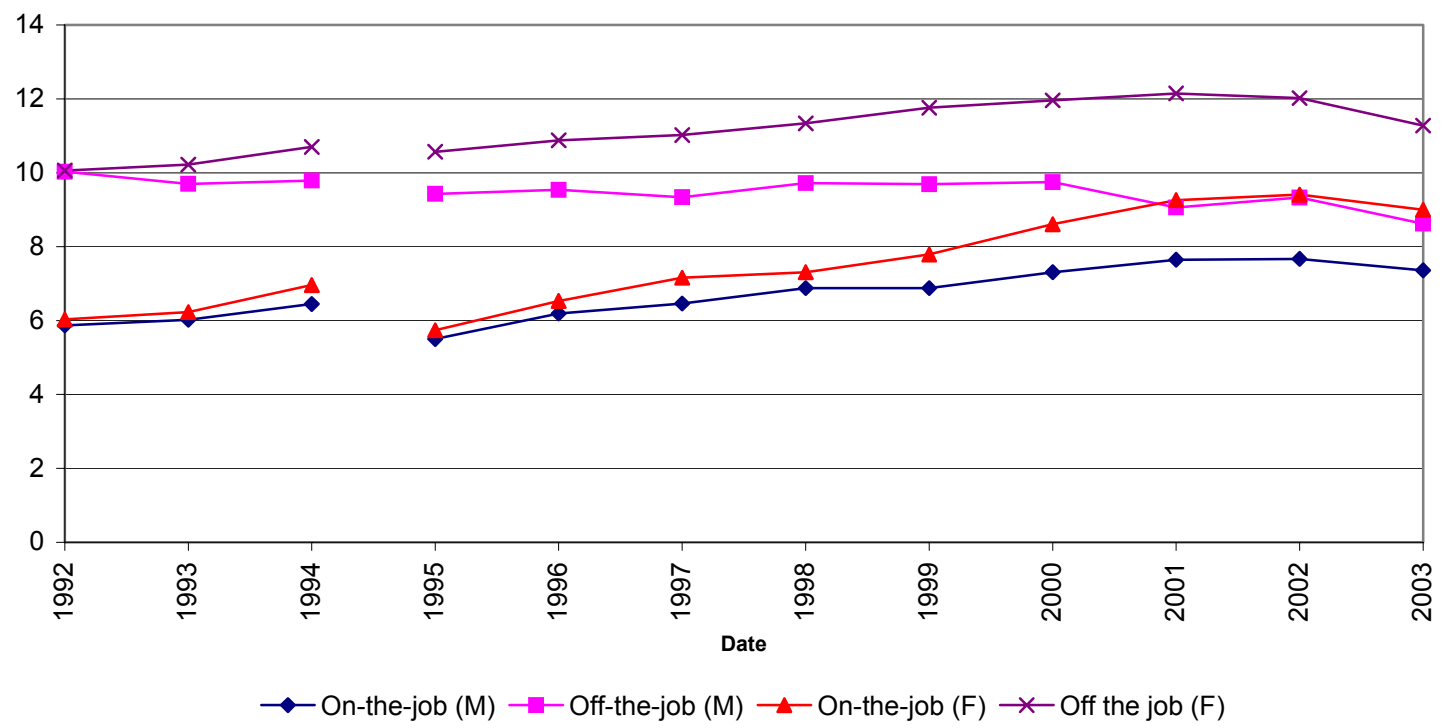

Notes: Data relate to estimation samples used below, and include employed persons of working age in Great Britain receiving job-related training in the last 4 weeks, excluding students, members of the armed forces and those on government training schemes. See notes to Figure 1 also.

Source: Authors' calculations based on Quarterly Labour Force Survey (Spring quarter). 
Finally, the issue of who pays for the training is clearly also important. While on-the-job training is clearly paid for by the employer, and this has risen more rapidly for women than for men since 1992, as Figure 2 makes clear, the larger absolute differential relates to off-thejob training, which has actually fallen for men, and which may be funded by either the employer or the employee. Figure 3 therefore presents a picture of the pattern over time in terms of employer-sponsored training, both off-the-job (where employer-sponsored is interpreted as the employer contributing to the payment of fees), and a composite measure adding on-the-job training to the previous measure. In terms of the former, the data reveal that women overtook men rather later (around 1997/8) on this indicator, with the differential in favour of females amounting to around 1 percentage point at the end of the sample period. For the composite employer-sponsored measure, as might be expected, the pattern is closer to the earlier picture.

\section{Figure 3: Percentage of employees receiving employer-sponsored training in the last 4} weeks

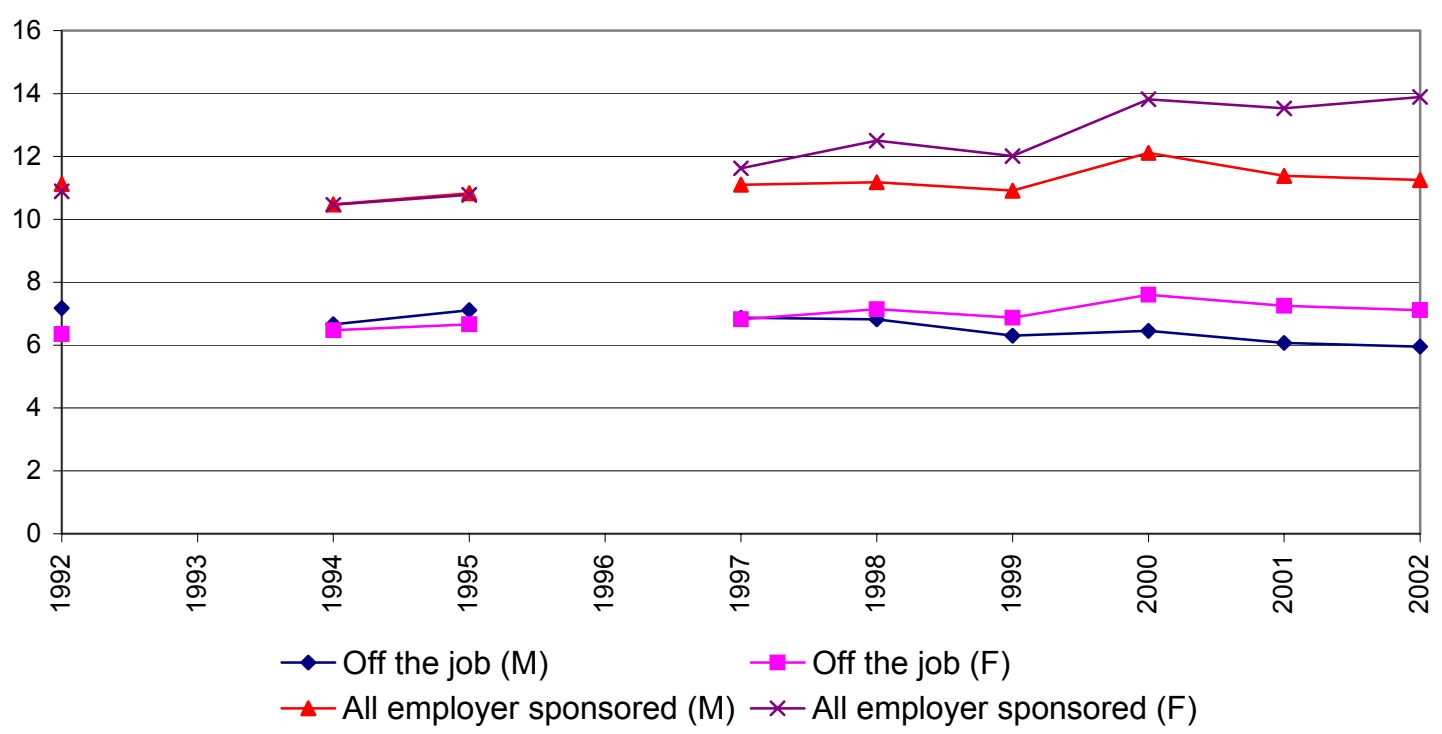

Notes: Data relate to estimation samples used below, and include employed persons of working age in Great Britain receiving job-related training in the last 4 weeks, excluding students, members of the armed forces and those on government training schemes. 'Employer sponsored' indicates the employer contributed to payment of fees for off-the-job training; all on-the-job training is treated as employer-sponsored. See notes to Figure 1 also. Data were not collected in the relevant quarter for 1992/3 and 1995/6.

Source: Authors' calculations based on Quarterly Labour Force Survey (Winter quarter). 
In our data set, descriptive statistics suggest little difference between men and women in the duration of training received, methods of study, or whether training leads to a qualification, conditional on incidence. It is not the case that, while being more likely to participate, women receive inferior training. Given that the major gender difference relates to incidence, the purpose of the present paper is accordingly to explore the sources of this differential in training incidence using Labour Force Survey data, updating previous U.K. studies and providing further insights into this intriguing phenomenon using several definitions of training along the lines identified above. However, in addition to examining the current gap in training incidence, we also analyse the factors underlying changes in training incidence over time. Given the reversal of the earlier gender gap in training receipt reported in the U.K. by earlier studies, which was sometimes cited as an example of discriminatory behaviour on the part of employers, together with the widening of the gap in favour of women in the last few years, we believe the paper addresses an important feature of the U.K. labour market, with relevance also to other economies.

The remainder of the paper is set out as follows. In Section 2 we discuss the estimation methodology, while section 3 details the data employed. Results are presented in Section 4 while conclusions appear in Section 5.

\section{Methodology}

The methodology for our empirical model is at first sight straightforward, although some care is required in interpretation of the results due to the potential for conflation of demand-side and supply-side effects (in this sense the estimated models should be regarded as reduced form specifications). 
The basic framework is essentially that used in a number of previous studies such as those of, inter alia, Booth (1991), Green (1993), Shields (1998) and Latreille et al. (2002), in which an individual will participate in training if the perceived net benefits (to employer and/or employee as appropriate) are positive. This decision may be modelled as a latent variable model in which the net benefit of training for males $(\mathrm{M})$ and females $(\mathrm{F})$ is given respectively by:

$$
\mathrm{Z}_{\mathrm{i}}^{\mathrm{M}}=\mathrm{X}_{\mathrm{i}}^{\mathrm{M}} \beta^{\mathrm{M}}+\varepsilon_{\mathrm{i}}^{\mathrm{M}}
$$

and

$$
Z_{i}^{F}=X_{i}^{F} \beta^{F}+\varepsilon_{i}^{F}
$$

where $\mathrm{X}$ is a vector of individual and firm characteristics, $\beta$ a conformable vector of coefficients, and $\varepsilon$ an error term, while the subscript $\mathrm{i}$ indexes individuals of each gender. In practice, $\mathrm{Z}$ is unobserved, and is replaced in the estimated models by its binary counterpart $\mathrm{T}$ if a training spell has been reported, i.e.:

$$
\left\{\begin{array}{ll}
\mathrm{T}_{\mathrm{i}}^{\mathrm{M}}=1 & \text { if } \mathrm{Z}_{\mathrm{i}}^{\mathrm{M}}>0 \\
\mathrm{~T}_{\mathrm{i}}^{\mathrm{M}}=0 & \text { if } \mathrm{Z}_{\mathrm{i}}^{\mathrm{M}} \leq 0
\end{array}\right\}
$$

and

$$
\left\{\begin{array}{ll}
\mathrm{T}_{\mathrm{i}}^{\mathrm{F}}=1 & \text { if } \mathrm{Z}_{\mathrm{i}}^{\mathrm{F}}>0 \\
\mathrm{~T}_{\mathrm{i}}^{\mathrm{F}}=0 & \text { if } \mathrm{Z}_{\mathrm{i}}^{\mathrm{F}} \leq 0
\end{array}\right\}
$$

The resulting empirical models are estimated straightforwardly as logits.

Since the focus of the paper is on gender differences in training incidence, we next focus on the mean predicted training probability differential between males and females, given by:

$$
\overline{\mathrm{T}}^{\mathrm{F}}-\overline{\mathrm{T}}^{\mathrm{M}}=\overline{\mathrm{P}}\left(\mathrm{X}_{\mathrm{i}}^{\mathrm{F}} \hat{\beta}^{\mathrm{F}}\right)-\overline{\mathrm{P}}\left(\mathrm{X}_{\mathrm{i}}^{\mathrm{M}} \hat{\beta}^{\mathrm{M}}\right)
$$


where $\bar{P}\left(X_{i}^{F} \hat{\beta}^{F}\right)=\frac{1}{n^{F}} \sum_{i} P\left(X_{i}^{F} \hat{\beta}^{F}\right)$ and $\bar{P}\left(X_{i}^{M} \hat{\beta}^{M}\right)=\frac{1}{n^{M}} \sum_{i} P\left(X_{i}^{M} \hat{\beta}^{M}\right)$, a circumflex denotes an estimate, $\mathrm{n}$ the number of observations and $\mathrm{P}($.$) the individual predicted probabilities. As$ is now well-established, the difference in (3) can be decomposed into a component due to group differences in observed characteristics and a component due to differences in coefficients in a number of ways, depending on the assumptions made concerning the structure that would prevail in the absence of differences in the group processes determining training receipt. A generalised description of these possibilities, following Gomulka and Stern (1990) is given by:

$$
\begin{aligned}
\overline{\mathrm{T}}^{\mathrm{F}}-\overline{\mathrm{T}}^{\mathrm{M}}=\left\{\overline{\mathrm{P}}\left(\mathrm{X}_{\mathrm{i}}^{\mathrm{F}} \hat{\beta}^{*}\right)-\overline{\mathrm{P}}\left(\mathrm{X}_{\mathrm{i}}^{\mathrm{M}} \hat{\beta}^{*}\right)\right\} \\
+\left[\overline{\mathrm{P}}\left(\mathrm{X}_{\mathrm{i}}^{\mathrm{F}} \hat{\beta}^{\mathrm{F}}\right)-\overline{\mathrm{P}}\left(\mathrm{X}_{\mathrm{i}}^{\mathrm{F}} \hat{\beta}^{*}\right)\right]+\left[\overline{\mathrm{P}}\left(\mathrm{X}_{\mathrm{i}}^{\mathrm{M}} \hat{\beta}^{*}\right)-\overline{\mathrm{P}}\left(\mathrm{X}_{\mathrm{i}}^{\mathrm{M}} \hat{\beta}^{\mathrm{M}}\right)\right]
\end{aligned}
$$

which is a version of the standard Blinder-Oaxaca 'aggregate' or aggregate decomposition, where $\hat{\beta}^{*}$ denotes the coefficient structure/regimen that would prevail in the absence of behavioural/treatment differences between the two groups. The first expression in \{\} on the right-hand side is the characteristic effect, while the second expression in \{\} is accordingly the coefficient effect ${ }^{6}$. While it is possible to use the male or female coefficients as this 'neutral' structure, this raises the usual issue concerning the 'index number problem'. For this reason, we instead prefer the procedure suggested by Neumark (1988) and Oaxaca and Ransom (1994), in which the 'neutral' coefficients are obtained from an identical regression pooling the male and female samples.

It is, of course, often of interest to determine the contributions of particular variables or groups of variables to the observed differential. A detailed decomposition (i.e. for individual

\footnotetext{
${ }^{6}$ The coefficient difference in this formulation (which also includes any 'unexplained' element due to omitted factors in $\mathrm{X}$ ) is, by convention, interpreted as 'discrimination'. Apart from the possibility of 'positive discrimination', this is not an interpretation that fits especially well in the present context, where females have the higher value of the variable of interest, and we therefore avoid its use here.

${ }^{7}$ Decompositions using the male and female coefficients as the baseline structure are available on request.
} 
variables) of the characteristics effect in the context of the non-linear methods used to estimate binary choice models has been proposed by Even and Macpherson (1990, 1993), in which the contribution of variable $\mathrm{k}$ to the observed differential is calculated as:

$$
\mathrm{C}_{\mathrm{k}}=\mathrm{W}_{\mathrm{k}}^{\Delta \mathrm{X}}\left[\overline{\mathrm{P}}\left(\mathrm{X}_{\mathrm{i}}^{\mathrm{F}} \hat{\beta}^{*}\right)-\overline{\mathrm{P}}\left(\mathrm{X}_{\mathrm{i}}^{\mathrm{M}} \hat{\beta}^{*}\right)\right]
$$

where, following the exposition in Yun (2004), the weight on each characteristic in $\mathrm{X}$ is given by ${ }^{8}$ :

$$
\mathrm{W}_{\mathrm{k}}^{\Delta \mathrm{X}}=\frac{\left(\overline{\mathrm{X}}_{\mathrm{k}}^{\mathrm{F}}-\overline{\mathrm{X}}_{\mathrm{k}}^{\mathrm{M}}\right) \hat{\beta}^{*}}{\left(\overline{\mathrm{X}}^{\mathrm{F}}-\overline{\mathrm{X}}^{\mathrm{M}}\right) \hat{\beta}^{*}}
$$

with $\sum_{\mathrm{k}=1}^{\mathrm{K}} \mathrm{W}_{\mathrm{k}}^{\Delta \mathrm{X}}=1$

In addition to the above decompositions, we also estimate the model at two points in time (1994/95 and 2000/01) so as to facilitate time-wise decompositions similar to those reported in Shields (1998). This restricted time period is a consequence of changes in the data, in particular changes to the occupational classification from the Spring quarter of 2001 and the discontinuity in the training questions noted previously. These time-wise decompositions essentially employ the same methodology as that set out above to consider the relative influence of changes in characteristics and changes in coefficients to the change in mean training incidence over the period (separately by gender), i.e. $\overline{\mathrm{T}}^{01, \mathrm{j}}-\overline{\mathrm{T}}^{95, \mathrm{j}}(\mathrm{j}=\mathrm{M}, \mathrm{F})$. Decompositions in this context are again evaluated on the basis of the pooled coefficients (in this case over time), i.e.

\footnotetext{
8 Yun (2004) has proposed a generalised methodology for performing 'detailed' decompositions of both characteristics and coefficient contributions including the case of non-linear functions such as the probit and logit, using male or female coefficients as the baseline structure. This methodology for obtaining a detailed decomposition of the coefficient effect was attempted, but encountered the situation common in the literature whereby the decomposition was dominated by the constant. Given the concerns raised by Jones (1983) and Cain (1986) concerning the interpretation of the constant in (wage) equations where the set of regressors includes dummy variables, the results reported here are restricted to decomposition of the characteristics component only and, for the sake of parsimony, using the pooled coefficients as the baseline structure.
} 


$$
\begin{aligned}
& \overline{\mathrm{T}}^{01, \mathrm{j}}-\overline{\mathrm{T}}^{95, \mathrm{j}}=\left[\overline{\mathrm{P}}\left(\mathrm{X}_{\mathrm{i}}^{01, \mathrm{j}} \hat{\beta}^{*, j}\right)-\overline{\mathrm{P}}\left(\mathrm{X}_{\mathrm{i}}^{95, \mathrm{\beta}} \hat{\beta}^{*, j}\right)\right\rfloor \\
& +\left\{\left[\overline{\mathrm{P}}\left(X_{\mathrm{i}}^{01, j} \hat{\beta}^{01, \mathrm{j}}\right)-\overline{\mathrm{P}}\left(\mathrm{X}_{\mathrm{i}}^{01, \mathrm{\beta}} \hat{\beta}^{*, j}\right)\right]+\left[\overline{\mathrm{P}}\left(\mathrm{X}_{\mathrm{i}}^{95, \mathrm{j}} \hat{\beta}^{*, j}\right)-\overline{\mathrm{P}}\left(\mathrm{X}_{\mathrm{i}}^{95, \mathrm{j}} \hat{\beta}^{95, \mathrm{j}}\right)\right]\right\}
\end{aligned}
$$

\section{The Data}

The empirical results presented below examine several definitions of training incidence using the Labour Force Survey. The current situation is analysed using the Winter quarter of $2002 / 3$ (this being the only quarter of each year for which details of the source of funding (see below) are available). Data from the corresponding quarters of 1994/95 and 2000/01 are used to perform the time-wise decompositions.

Respondents are initially asked': 'In the 3 months since beginning [date] have you taken part in any education or any training connected with your job, or a job that you might be able to do in the future?'. For those who answer in the affirmative ${ }^{10}$, this is then followed by the question '.. and did you take part in any of that education or training in the 4 weeks ending Sunday the [date]?'. Those who have received training during this period are subsequently asked 'Was (is) that training... 'on-the-job' training only, or training away from your job, or both?'. Finally, individuals who had received any 'off-the-job' training are asked 'Who paid the fees for this training?'. From these questions, five binary dependent variables were created corresponding to the variables in Figures 1-3, where in each case the value 1 indicates participation in (the identified type of) training, while a 0 denotes non-participation. The first variable simply considers the receipt of any training during the 4 weeks preceding the interview [TRAIN4WK]. The next two variables [TRAINON and TRAINOFF] denote

\footnotetext{
${ }^{9}$ Given that the LFS is a household survey, a slightly modified form of words is used where the respondent is answering on behalf of another household member (i.e. a 'proxy interview'). As Green and Zanchi (1997) note, this practice may result in erroneous responses (more generally, false negatives, especially for males). We therefore follow their approach by including a dummy variable in the estimated models taking the value in the event of a proxy interview and 0 otherwise.

${ }^{10}$ It is the introduction of this requirement that results in the discontinuity identified in Figure 1 (see notes there).
} 
receipt of 'on-the-job' and 'off-the-job' training respectively (individuals who have received both types of training will, by definition, have unit values for both variables), while the penultimate dependent variable concerns employer-funded off-the-job training [TRAINEMPOFF], where training is deemed to be employer funded if the employer was reported as contributing either wholly or partly to the cost of the training. Since on-the-job training is, by definition, employer funded, the final training incidence measure [TRAINEMP] indicates the receipt of any employer-funded training, regardless of whether this is of the on-the-job or off-the-job variety or both (i.e. TRAINON $=1$ or TRAINEMPOFF=1).

The candidate variables included in $\mathrm{X}$ are for the most part, standard and well-established in the previous literature. Thus we include personal characteristics such as age, marital status, number of dependent children (if head of household or their spouse), disability, ethnicity and highest qualification, together with job- and employer-related characteristics such as tenure, full-time/part-time and permanent/temporary employment status, second job-holding, occupational group, industrial sector, employer ownership (public/private sector), employer size and region ${ }^{11}$. The same set of controls is adopted for each of the various types of training described above, the expectation being that at least some of the influences will differ among the different training definitions. The sample is restricted to employed individuals of working age, excluding students, the self-employed, unpaid family workers, members of the armed forces, those on government training schemes, and residents of Northern Ireland.

\footnotetext{
${ }^{11}$ One obvious omission from this list is union membership. Unfortunately, this variable is only available in the Autumn quarter of the LFS. If one were prepared to assume that union status does not change between quarters, it is possible to include this among the list of explanatory variables, albeit at the cost in terms of sample size (see Section 4.3).
} 


\section{4. $\quad$ Results}

\subsection{Summary statistics}

Summary statistics for the 2003 estimation samples are presented in Table 1, which reveals a number of interesting patterns. First, the distributions for men and women look very similar in respect of many of the variables, including region, ethnicity, marital status, age and tenure, although the proportion of males aged 50 and over is slightly higher than for females, as is the proportion with tenure in excess of 5 years. Small differences also exist for the presence of dependent children, working in a small firm and in a temporary job, and also holding a second job, all of which are more evident for women. More substantial differences exist in terms of highest qualifications: to a modest extent in respect of 'Other higher education' (mainly teaching and nursing qualifications), and to a considerable extent for A levels and $\mathrm{O}$ levels or their equivalents. As might be expected, substantially more women work in the public sector compared with men (36\% and 19\% respectively). More dramatic still is the occupational distribution: far higher proportions of women work in administrative/clerical, personal service and sales/customer service occupations than of males, with the latter instead being more heavily represented in skilled trades and among process, plant and machine operatives. Accordingly, men are more likely to work in manufacturing and construction while women, reflecting their higher incidence of public sector employment, are substantially over-represented in public administration, education and health. Importantly, women are also much more likely to work part-time, which may be expected to impact negativelyon their receipt of training.

At first sight therefore, there are substantial differences between males and females which may go some way to explaining the training differential described above. In large part however, these characteristics differences appear to relate to the type of work and employer 
rather than what might be thought of as human capital attributes, such as experience and qualifications. The effect of these variables on each of the training measures, delineated earlier, is the subject of the remainder of this paper. To this end, Tables 2-6 detail the regression estimates for each of the five training measures, with coefficients reported separately for males, for females, and on the basis of the pooled sample.

\subsection{Regression results}

As can be seen from Tables 2-6, the models are generally well-determined. While many of what might be regarded as the 'core' variables are quantitatively similar for men and women, in each case the pooling restriction is comfortably rejected at the 1 per cent significance level: coefficient differences therefore do appear to be contributing to the gender training gap. The relative extent of coefficient and characteristic differences is evaluated later in Section 4.5.

As might be expected given the overlap between the various training measures, many of the determinants of training incidence operate in a similar fashion across the alternative definitions. For the sake of parsimony, we attempt to discern the regularities in the estimates, rather than attempting a blow-by-blow account of each set of estimates. Where substantive differences exist for alternative training definitions, these are also highlighted.

In almost all previous studies, a key role has been played by age, reflecting the predictions of orthodox human capital theory, whereby the probability of training participation declines with age, reflecting the shorter period over which the costs of training may be amortised. This pattern is clearly evident in each of the sets of estimates considered here, with the probability of training incidence being higher for those in each age group relative to the omitted category (50 and over), highest for workers aged 16-17 (whose positions are often 
training posts by definition), and with coefficients typically becoming smaller for successive age dummies. As in the majority of previous UK studies (see inter alia Arulampalam and Booth, 1998, Booth et al., 1999, Green, 1993, 1994, Green et al., 1999, Greenhalgh and Mavrotas, 1994, 1996, Shields and Wheatley Price, 1999, and for later years in his sample, Shields, 1998), there is also strong evidence to support the view that training receipt is positively associated with educational attainment for each of the training measures (the omitted category being no qualifications), albeit that the relationship is less obviously welldefined for on-the-job training among females.

In respect of other personal characteristics, there is little to suggest any ethnic dimension to training receipt, while marital status and the presence of dependent children in the household do not appear to exert any consistent impact. A more consistent pattern is evident in respect of (self-reported) disability. Ceteris paribus, disabled workers appear more likely to participate in job-related education and training than other workers (Table 2), and whereas for women this association holds for both on- and off-the-job training types but not for employersponsored off-the-job training, for men it appears to be restricted to off-the-job training and employer-supported off-the-job forms, rather than on-the-job training.

Given that a proportion of training spells will comprise induction training activities, it is perhaps unsurprising that the probability of participation in job-related education or training is higher among those with shorter tenures. Much of this training is likely to be of an on-thejob variety (Table 3), and it accordingly comes as little surprise that this pattern does not hold for its counterpart, off-the-job training, regardless of whether the employer contributes to the training (see Tables 4 and 5). This seems likely to reflect the conventional view that, in competitive labour markets at least, employers are less likely to provide training of a more 
general variety due to the risk of labour turnover. New hires are, in this sense, more risky: not only is there an asymmetry of information between employee and employee in terms of worker quality, but with the exception of first-time entrants to the labour market, new hires will already have a record of separation from a previous employer (albeit for some, this may not have been through choice).

Being on a temporary contract, as would be expected, is typically associated with a lower probability of training participation: for both employer and employee the temporary nature of the contract reduces the expected payoff to any training ${ }^{12}$, and consequently the value of any investment in the worker's skills. Given the lower payoff/longer expected payback period for part-time workers, it is entirely unsurprising that training incidence of all types is significantly lower for this group also (the only exception being for off-the-job training for males). In contrast, possession of a second job typically enhances the probability of receiving training, although only for males in the context of employer funded training (i.e. on-the-job and off-the-job training to which the employer contributed). In this sense at least therefore, there is a suggestion of gender discrimination of the more orthodox variety discussed by previous authors.

Other attributes of the job also exert a powerful influence over participation in all forms of training considered here. Thus, for both men and women, the occupational dummy variables are strongly related to training participation, although individual significance depends to some extent on the training measure considered. In general, however, training is higher relative to the Managerial omitted base group for those in Professional and Associate professional occupations, and lower for the remaining groups, but especially so for those in

\footnotetext{
${ }^{12}$ The distinction between general and specific training is likely to be important here. For the employee, the disincentive is largely to undertake specific training; general training, which improves their labour market appeal, may actually be more desirable as a result of the temporary nature of their job.
} 
Sales and customer services, Process, plant and machine operatives and Elementary occupations. The only (slight) departure from this pattern occurs in the context of on-the-job training, where training participation is notably higher among those in Personal service occupations.

Employer characteristics too are important. In particular, workers in the public sector are consistently more likely to have participated in job-related education and training of all types, confirming the public-private sector training gap highlighted by Latreille et al. (2002). In contrast, being in a small firm reduces the chances of participation. In part this last result is likely to reflect the higher per unit costs of training provision associated with training in small firms, where economies of scale in training provision are likely to be absent, and the costs of foregone output in on-the-job training relatively greater.

The data also indicate that the industry in which the employer operates is of some import in determining training participation. The results in Tables 2-6 imply that training is more likely in the Energy and water industries, and to an even greater extent in Public administration, education and health, in accordance with the earlier discussion of sectoral effects. In a number of cases, the coefficients and their significance vary between the genders, and also among the training forms. Looking at Tables 5 and 6 , which consider employer contributions to training, in contrast to the above positive coefficients, training incidence appears lower in Manufacturing, and in Distribution, hotels and restaurants. In terms of regional effects, only modest evidence of these is apparent for males, with rather greater evidence for such effects for females, although again there is some variation in significance of individual regional dummies across training types. 
Finally, the dummy variable indicating that the LFS interview was with a proxy respondent is negative throughout, and with only a couple of exceptions, statistically significant. This confirms the point made by Green and Zanchi (1997) that it is important to control for respondent bias when using these data.

\subsection{The Effect of Unions}

As noted earlier, including union variables substantially reduces sample size (by over onethird), so we have chosen not to include any union variables in our main regressions. However, past British work on the determinants of training has generally reported a positive union effect (see, for example, Greenhalgh and Mavrotas, 1994; Green, Machin and Wilkinson, 1999; and Böheim and Booth, 2004). In contrast, a recent paper by Addison and Belfield (2004), using WERS 1998, finds that whether or not a worker receives training is not affected by the union recognition status of a plant or by the structure of collective bargaining and the same is true for training duration and overall union recognition, although there are important differences according to types of union recognition.

Our data suggest little difference in the extent of union membership and union recognition between men and women $-31.6 \%$ of men being union members and $31.5 \%$ of women, while $37.5 \%$ of men are covered by a collective agreement and $39.6 \%$ of women ${ }^{13}$. The regression results reveal that both union variables (entered separately) significantly increase the probability of training for both men and women over each of the five categories of training

\footnotetext{
${ }^{13}$ If the comparison is limited to full-time workers 16 and over, union density is $31 \%$ for men and $34 \%$ for women in the Autumn of 2003, and density is higher for women in all age groups. Density is also much higher for part-time women than men ( $23 \%$ as opposed to $12 \%)$, but because there are more part-time women and density is lower for this group, the percentages for all workers are identical by gender at $29 \%$ (Hinks and Palmer, 2004). That this convergence of male and female union density is long term is indicated in a paper by Machin (2004) who shows that in $197566 \%$ of men were union members, compared to $40 \%$ of women. Decompositions over the period 1975-2001 suggest that only $20 \%$ of the change is the result of compositional change.
} 
(results available on request). The effect is particularly strong for female union members in relation to employer-funded training. Here, it is worth remarking on a recent paper by Melero (2004). Using a sample of workers from twelve waves of the BHPS (1991-2002) he found that whereas job-related training significantly boosted the chances of women being promoted; no such effect was detected for male workers.

\subsection{Testing Imperfect Competition Models}

In order to test the Acemoglu and Pischke imperfect competition model we first substituted a job density measure for the regional dummy variables. Job density is defined as the number of jobs per person of working age resident in that area ${ }^{14}$. Job density by standard statistical region was then mapped on to individual data. Using 2003 data for all workers, the job density variable always has the expected negative sign and is significant for any training (1\% level) and on-the-job training (5\% level). When split by gender it is significant for men for any training (at the $10 \%$ level), on the job training (at the 5\% level) and employer-financed on-the-job training (10\% level), but in no case is it significant for women. Further, when similar regressions were run for 1995 and 2001 the job density measure was sometimes positively signed and never significant. It seems unlikely, therefore, that changes in job density can explain the relative gain in training opportunities for women.

Second, we attempted to test the wage compression model, using derived hourly pay to construct two measures of wage compression, generating the $10^{\text {th }}$ and $90^{\text {th }}$ percentiles of the hourly pay distribution. Relative wage compression was measured as $\left[\log \left(90^{\text {th }} / 10^{\text {th }}\right)\right]$ and absolute wage compression as $\left[\log \left(90^{\text {th }}-10^{\text {th }}\right)\right]$. These measures were constructed by education (6 groups) and occupation (9 groups) and then mapped to individual employees.

\footnotetext{
${ }^{14}$ Data for 2002 from Nomis. Estimates of total workforce jobs are workplace-based, and measure jobs rather than people. Total jobs consist of employees, self employed, armed forces personnel and government-supported trainees. These results are available from the authors on request.
} 
According to the above hypothesis, the expected sign is negative, but in practice both our measures were consistently positively signed and sometimes significant. It is possible that establishment level data, such as WERS, are necessary to conduct a proper test of the wage compression hypothesis, but given the mixed results for these variables and the job density measure, we have reported our main results with these variables excluded.

\subsection{Decomposition results (2003)}

Using the results from Tables 2-6 inclusive, we next decomposed the gender differential for each of the training measures as described in Section 2 into a component due to differences in coefficients and a component due to differences in characteristics. As noted earlier, this task is undertaken using the pooled coefficients as indicative of the returns to particular attributes, and the results of doing so are presented in Table 7. A number of features of this table stand out.

The first is that the coefficient (unexplained) component varies between 30 and 63 per cent depending on the measure under consideration. Interestingly, it is around one third for the any training, on-the-job and off-the-job measures, but is higher (around 60 per cent) when considering only those definitions that include employer contributions. For all except these last two measures therefore, the majority of the training differential is 'explained' by differences in attributes between men and women. It is perhaps in the sense of the larger coefficient effect that the view that women may receive favourable treatment in respect of training receipt receives some support.

Given the substantial characteristics contribution in the decompositions, further insights can also be obtained by considering the contributions of individual variables or groups of 
variables to the aggregate characteristics component, following the method of Even and Macpherson $(1990,1993)$ as described in Section 2. As can be seen in the lower panels of Table 7 , the detailed decompositions are dominated by four variables/groups of variables: whether the individual works in the public sector, whether they work part-time, occupation and industry. The first, third and fourth of these between them explain more than the whole of the characteristics component of the training differential in all cases. The impact of working part-time, which is of course, largely a female phenomenon, and associated with a lower probability of receiving each of the forms of training considered here for both men and women, is that women would be even more likely to receive training were it not for this particularly unfavourable characteristic ${ }^{15}$.

\subsection{Time-wise Decompositions}

Ideally one would wish to estimate time-wise decompositions for the full-period 1984-2003, but this is not possible because of the change in questionnaire design in 1995 reported earlier and a change to the occupational classification in 2001. Hence, we restrict ourselves the period 1995-2001, which fortuitously is the period when female training advanced most substantially relative to that of men, and is also a period of training growth. Since the regression results are qualitatively similar to those presented above for 2003, we do not report them here, but limit ourselves to consideration of the decomposition results contained in Table 8. Table 8 includes gender decompositions at each of the two dates and decompositions over time for each gender. The detailed decompositions are calculated for the any training measure. In 1995 (Table 8(a)) differences in characteristics are responsible for the vast majority of differences in training provision between men and women for any training and off-the-job training, while in the other three cases incidence is over-explained by

\footnotetext{
${ }^{15}$ The training differentials favour of women in fact exist for both full- and part-time employees, and are larger when restricting attention to just full-time employees.
} 
characteristics. In each case, however, the explained component is reduced by 2001 (8(b)), so that changes in characteristics in favour of women are not the main cause of the gain in relative training incidence for this group. When examining the impact of specific characteristics at the two dates, the results in Table 8(e) suggest that working part-time, industry, occupation and sector are important in both years, while the relative significance of qualifications appears to have diminished somewhat.

Examining the time-wise decompositions for males between 1995 and 2001 (8(c)), hardly any of the changes can be explained by changes in characteristics, apart from the case of offthe-job training with employer contributions. For women, differences due to coefficients also dominate those due to characteristics $(8(\mathrm{~d}))$, though the latter are more important for women than for men. It appears therefore, that the explanation for the increase in the amount of training received by women or men cannot be explained by variables within our model, whether in terms of personal characteristics or nature of employment ${ }^{16}$. This is consistent with the evidence in Shields (1998), who in an earlier period of training growth (1984-89) found that only 20 per cent of the change was explained by changes in characteristics. The evidence therefore suggests that it is changes in the preferences of firms and/or workers for training that has caused the observed increase in incidence. For women, that part of the change in incidence that is due to characteristics appears to be dominated by qualifications and by occupation $(8(e))$.

\footnotetext{
${ }^{16}$ When the regressions were run including union membership dummies for 1995 and 2001 for the any training variable, and time-wise decompositions calculated, $82 \%$ of the male/female difference in training was explained in 1995 , but only $68 \%$ in 2001 . Comparing males in 1995 with males in 2001 the proportion explained is $-2 \%$, while for women the proportion is $38 \%$; only slightly greater than the specification without a union variable. Thus, the exclusion of unions in our main regressions is not driving our results.
} 


\section{Conclusions}

In this paper, we have considered the striking feature evident in the Labour Force Survey that women are more likely to receive job-related education and training in the 4 weeks prior to interview than are males. This differential exists for several different definitions of training: any training, on- and off-the-job training, off-the-job training with a employer contribution, and any training involving an employer contribution.

Using decomposition analysis, the greater part of the gap for the first three measures of training is explicable in terms of personal, job and other characteristics that favour women, most notably sector, occupation and industry. As would be expected, female training incidence would in fact be even higher were it not for the fact that so many women work part-time; a status that encourages neither employer nor worker to invest in training. For training involving an employer contribution, more of the gap is due to coefficient differences, and indeed, on the basis of pooled estimates, more than half of the differential is attributable to such differences.

Consideration of changes over time (restricted to 1995-2001 due to data changes), suggests that most of the increase in training incidence for men and women is due to changes in coefficients rather than characteristics. This suggests that changes in preferences may underpin this feature of the labour market, perhaps reflecting changes in the returns to training. For that part of the change that is due to characteristics, the majority is attributable to qualifications and occupation.

The phenomenon considered here is an interesting and potentially important one, since it has generally been the case that females have been disadvantaged in the labour market. Our 
results suggest that characteristics explain most of the current gender differential in favour of women, but that changes in coefficients explain the bulk of the changing incidence over time. 


\section{REFERENCES}

ACEMOGLU, D. and PISCHKE, J.S. (1998) 'Why do firms train? Theory and evidence', Quarterly Journal of Economics, Vol. 113(1), pp. 79-119

ACEMOGLU, D. and PISCHKE, J.S. (1999a) 'The structure of wages and investment in general training', Journal of Political Economy, Vol. 107(3), pp. 539-572

ACEMOGLU, D. and PISCHKE, J.S. (1999b), 'Beyond Becker: Training in imperfect labour markets', Economic Journal, Vol. 109, pp. F112-F142

ADDISON, J.T. and BELFIELD, C.R. (2004), 'Unions, training and firm performance: Evidence from the British Workplace Employee Relations Survey', IZA Discussion Paper, No. 1264

ALMEIDA-SANTOS, F. and MUMFORD, K. (2004), 'Employment training and wage compression in Britain', IZA Discussion Paper, No. 1197

ARULAMPALAM, W. and BOOTH, A.L. (1997) 'Who gets over the training hurdle? A study of the training experiences of young men and women in Britain', Journal of Population Economics, Vol. 10(2), pp. 197-217

ARULAMPALAM, W. and BOOTH, A.L. (1998) 'Training and labour market flexibility: Is there a trade-off?', British Journal of Industrial Relations, Vol. 36(4), pp. 521-536

ARULAMPALAM, W., BOOTH, A.L. and BRYAN, M.L. (2003), 'Training in Europe', IZA Discussion Paper, No. 933

BARRON, J.M., BLACK, D.A. and LOEWENSTEIN, M.A. (1993) 'Gender differences in training, capital, and wages', Journal of Human Resources, Vol. 28(2), pp. 343-364

BLUNDELL, R., DEARDEN, L. and MEGHIR, C. (1996) The Determinants and Effects of Work-Related Training in Britain, London: Institute for Fiscal Studies

BOHEIM, R. and BOOTH, A.L. (2004), 'Trade union presence and employer provided training in Great Britain', Industrial Relations, Vol. 43, July, pp. 520-545

BOOTH, A.L. (1991) 'Job related formal training: Who receives it and what is it worth?', Oxford Bulletin of Economics and Statistics, Vol. 53(3), pp. 281-294

BOOTH, A.L. (1993) 'Private sector training and graduate earnings', Review of Economics and Statistics, Vol. 75(1), pp. 164-170

BOOTH, A. L., FRANCESCONI, M. and ZOEGA, G. (1999) 'Training, rent-sharing and unions', Birkbeck College: Economics Discussion Paper, 16/99.

BRUNELLO, G. and GAMBAROTTO, F. (2004), 'Agglomeration effects on employerprovided training: evidence for the UK', IZA Discussion Paper, No. 1055 
CAIN, G.G. (1986) 'The economic analysis of labor market discrimination: a survey', Handbook of Labor Economics, Vol. 1, Ashenfelter, O. and R. Layard (eds.), Amsterdam: North Holland

DEARDEN, L., MACHIN, S., REED, H. and WILKINSON, D. (1997) Labour Turnover and Work-Related Training, London: Institute for Fiscal Studies

DEX, S., JOSHI, H. and MACRAN, S. (1996) 'A widening gulf among Britain's mothers', Oxford Review of Economic Policy, Vol. 12(1), pp. 65-75

EVEN, W.E. and MACPHERSON, D.A. (1990) 'Plant size and the decline of unionism', Economics Letters, Vol. 32(4), pp. 393-398

EVEN, W.E. and MACPHERSON, D.A. (1993) 'The decline of private-sector unionism and the gender wage gap', Journal of Human Resources, Vol. 28(2), pp. 279-296

EVERTSSON, M. (2004) 'Formal on-the-job training: A gender-typed experience and wagerelated advantage?’ European Sociological Review, Vol. 20(1), pp. 79-94

GIBBINS, C. (1994) 'Women and training - data from the Labour Force Survey', Employment Gazette, November, pp. 391-402

GOMULKA, J. and STERN, N. (1990) 'The employment of married women in the United Kingdom 1970-1983', Economica, 57(226), pp. 171-199.

GREEN, F. (1991) 'Sex-discrimination in job-related training', British Journal of Industrial Relations, Vol. 29(2), pp. 295-304

GREEN, F. (1993) 'The determinants of training of male and female employees in Britain', Oxford Bulletin of Economics and Statistics, Vol. 55(1), pp. 103-122

GREEN, F. (1994) 'The determinants of training of male and female employees, and some measures of discrimination', in R. McNabb and K. Whitfield (eds.) The Market for Training: International Perspectives on Theory, Methodology and Policy, Aldershot: Avebury

GREEN, F. and ZANCHI, L. (1997) 'Trends in the training of male and female workers in the United Kingdom', British Journal of Industrial Relations, Vol. 35(4), pp. 635-644

GREEN, F., MACHIN, S. and WILKINSON, D. (1999) 'Trade unions and training practices in British workplaces', Industrial and Labor Relations Review, Vol. 52(2), pp 179-195.

GREENHALGH, C. and MAVROTAS, G. (1994) 'Workforce training in the Thatcher era: market forces and market failure', in R. McNabb and K. Whitfield (eds.) The Market for Training: International Perspectives on Theory, Methodology and Policy, Aldershot: Avebury

GREENHALGH, C. and MAVROTAS, G. (1996) 'Job training, new technology and labour turnover’, British Journal of Industrial Relations, Vol. 34(1), pp. 131-150 
GREENHALGH, C. and STEWART, M. (1997) 'The effects and determinants of training', Oxford Bulletin of Economics and Statistics, Vol. 49(2), pp. 171-189

HARRIS, R.I.D. (1999) 'The determinants of work-related training in Britain in 1995 and the implications of employer size', Applied Economics, Vol. 31(4), pp.451-463

HINKS, S. and PALMER, T. (2004), 'Trade union membership: Estimates from the Autumn 2003 Labour Force Survey”, Labour Market Trends, March, pp. 99-101

HOQUE, K. and KIRKPATRICK, I. (2003) 'Non-standard employment in the management and professional workforce: training, consultation and gender implications', Work Employment and Society, Vol. 17(4), pp. 667-689

JONES, F.L. (1983) 'On decomposing the wage gap: a critical comment on Blinder's method', Journal of Human Resources, 18(1), pp. 126-130

KEAVENY, T.J. and INDERRIEDEN, E.J. (1999) 'Gender differences in employersupported training and education', Journal of Vocational Behavior, Vol. 54(1), pp. 71-81

KNOKE, D. and ISHIO, Y. (1998) 'The gender gap in company job training', Work and Occupations, Vol. 25(2), pp. 141-167

LATREILLE, P.L., BLACKABY, D.H., MURPHY, P.D. and O'LEARY, N.C. (2002) 'The public-private sector training gap for full-time male employees in Britain: Evidence from SCELI', University of Wales Swansea Economics Discussion Paper, No. 2002-10

LYNCH, L. and BLACK, S.E. (1998) 'Beyond the incidence of employer-provided training', Industrial and Labor Relations Review, Vol. 52(1), pp. 64-81

MACHIN, S. (2004) 'Factors of convergence and divergence in union membership', British Journal of Industrial Relations, Vol. 42(3), pp. 423-438

MELERO, E. (2004), 'Training and career paths: human capital, information and incentives', IZA Discussion Paper, No. 1377

MILLER, P.W. (1994) 'Gender discrimination in-training - an Australian perspective', British Journal of Industrial Relations, Vol. 32(4), pp. 539-564

NEUMARK, D. (1988) 'Employers' discriminatory behavior and the estimation of wage discrmination', Journal of Human Resources, Vol. 23(3), pp. 279-295.

OAXACA, R. AND RANSOM, M. (1994), 'On discrimination and the decomposition of wage differentials', Journal of Econometrics, Vol. 61(1), pp. 5-21.

OLSEN, R.N. and SEXTON, E.A. (1996) 'Gender differences in the returns to and the acquisition of on-the-job training', Industrial Relations, Vol. 35(1), pp. 59-77

ROYALTY, A.B. (1996) 'The effects of job turnover on the training of men and women', Industrial and Labor Relations Review, Vol. 49(3), pp. 506-521 
SHIELDS, M. (1998) 'Changes in the determinants of employer-funded training for full-time employees in Britain, 1984-94', Oxford Bulletin of Economics and Statistics, Vol. 60(2), pp. $189-214$

SHIELDS, M.A. and WHEATLEY PRICE, S. (1999) 'Ethnic differences in the incidence and determinants of employer-funded training in Britain', Scottish Journal of Political Economy, Vol. 46(5), pp 523-551.

SIMPSON, P.A. AND STROH, L.K. (2002) 'Revisiting gender variation in training', Feminist Economics, Vol. 8(3), pp. 21-53

VEUM, J.R. (1996) 'Gender and race differences in company training', Industrial Relations, Vol. 35(1), pp. 32-44

WOODEN, M. and VANDENHEUVEL, A. (1997) 'Gender discrimination in training: A note', British Journal of Industrial Relations, Vol. 35(4), pp. 627-633

YUN, M.-S. (2004) 'Decomposing differences in the first moment', Economics Letters, Vol. 82(2), pp. $275-280$ 
Table 1: Means of variables

\begin{tabular}{|c|c|c|}
\hline Variable & Male & Female \\
\hline Age 16-17 & 0.01 & 0.01 \\
\hline Age 18-21 & 0.05 & 0.05 \\
\hline Age 22-24 & 0.05 & 0.05 \\
\hline Age 25-34 & 0.24 & 0.24 \\
\hline Age 35-49 & 0.39 & 0.43 \\
\hline Job tenure less than 3 months & 0.04 & 0.04 \\
\hline Job tenure 3-6 months & 0.06 & 0.06 \\
\hline Job tenure 6-12 months & 0.08 & 0.08 \\
\hline Job tenure $1-2$ years & 0.11 & 0.12 \\
\hline Job tenure $2-5$ years & 0.22 & 0.24 \\
\hline Degree & 0.20 & 0.18 \\
\hline Other higher education & 0.09 & 0.12 \\
\hline A level & 0.31 & 0.17 \\
\hline O level & 0.17 & 0.28 \\
\hline Other qualification & 0.13 & 0.14 \\
\hline North & 0.05 & 0.05 \\
\hline Yorkshire and Humberside & 0.10 & 0.09 \\
\hline East Midlands & 0.08 & 0.07 \\
\hline East Anglia & 0.04 & 0.04 \\
\hline South West & 0.09 & 0.09 \\
\hline West Midlands & 0.10 & 0.09 \\
\hline North West & 0.10 & 0.10 \\
\hline Wales & 0.05 & 0.05 \\
\hline Scotland & 0.09 & 0.10 \\
\hline Disabled & 0.22 & 0.21 \\
\hline White & 0.94 & 0.95 \\
\hline Dependent children & 0.68 & 0.72 \\
\hline Public sector & 0.19 & 0.36 \\
\hline Small firm & 0.24 & 0.29 \\
\hline Proxy & 0.38 & 0.22 \\
\hline Married & 0.61 & 0.60 \\
\hline Part-time & 0.05 & 0.40 \\
\hline Temporary & 0.04 & 0.06 \\
\hline Professional occupations & 0.14 & 0.11 \\
\hline Associate professional & 0.13 & 0.14 \\
\hline Administrative and secretarial & 0.06 & 0.25 \\
\hline Skilled trades & 0.17 & 0.02 \\
\hline Personal service occupations & 0.02 & 0.13 \\
\hline Sales and customer services & 0.03 & 0.11 \\
\hline Process, plant and machine operatives & 0.14 & 0.03 \\
\hline Elementary & 0.12 & 0.11 \\
\hline Agriculture and fishing & 0.01 & 0.00 \\
\hline Energy and water & 0.02 & 0.01 \\
\hline Manufacturing & 0.25 & 0.09 \\
\hline Construction & 0.09 & 0.01 \\
\hline Distribution, hotels and restaurants & 0.16 & 0.21 \\
\hline Transport and communication & 0.10 & 0.04 \\
\hline Banking and finance & 0.16 & 0.15 \\
\hline Public admin, education and health & 0.17 & 0.43 \\
\hline Second job & 0.03 & 0.05 \\
\hline
\end{tabular}

Notes: Means refer to estimation samples used. Data from the LFS Winter quarter 2002/03. 
Table 2: Participation in job-related education or training in the last 4 weeks

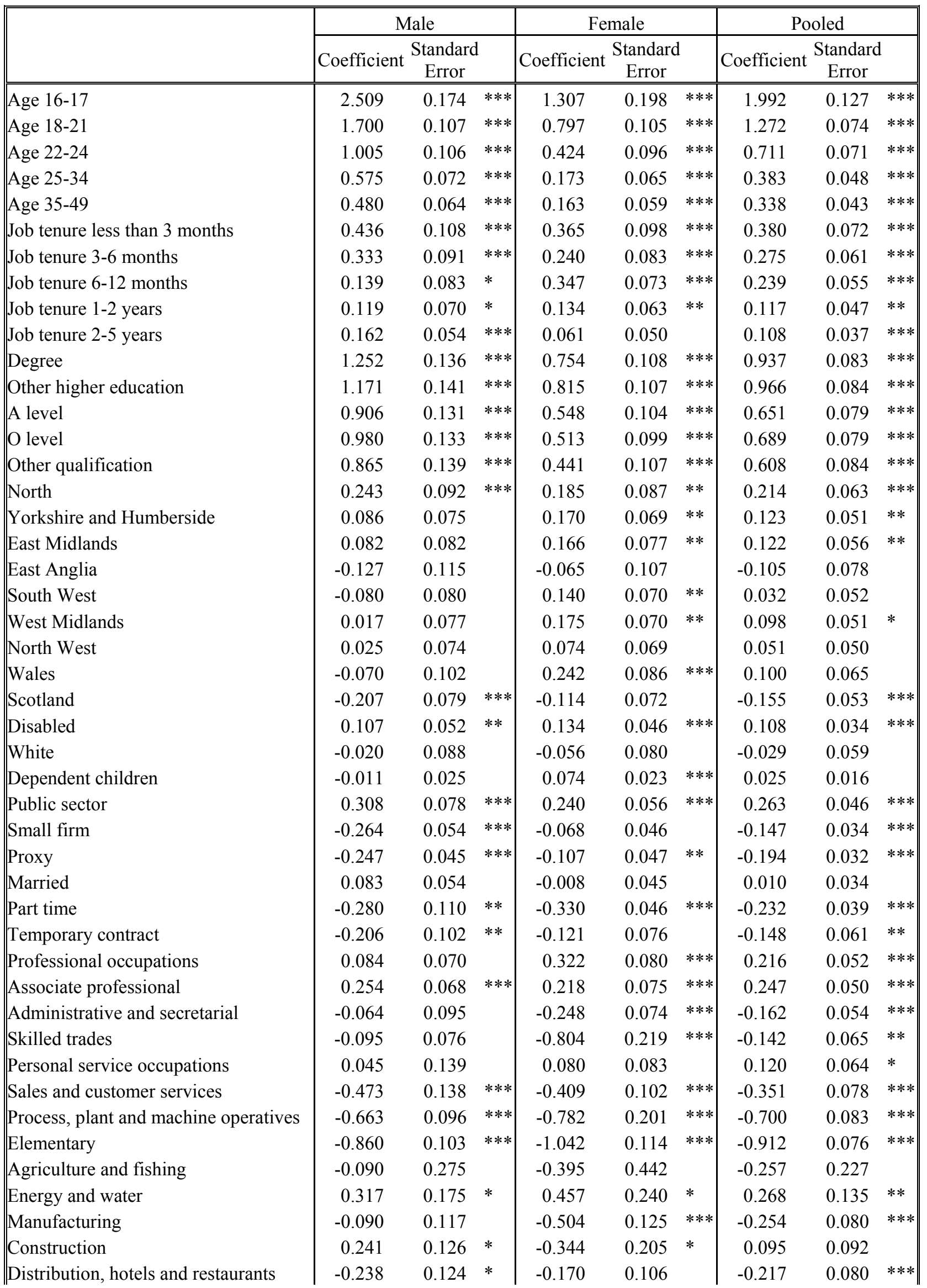




\begin{tabular}{|c|c|c|c|c|c|c|c|c|}
\hline Transport and communication & 0.032 & 0.128 & & -0.228 & 0.137 & * & -0.093 & 0.089 \\
\hline Banking and finance & 0.156 & 0.116 & & 0.049 & 0.098 & & 0.095 & 0.075 \\
\hline Public admin, education and health & 0.358 & 0.116 & $* * *$ & 0.292 & 0.090 & *** & 0.376 & 0.071 \\
\hline Second job & 0.375 & 0.106 & $* * *$ & 0.232 & 0.081 & $* * *$ & 0.265 & 0.064 \\
\hline Constant & -3.444 & 0.202 & $* * *$ & -2.501 & 0.169 & $* * *$ & -2.944 & 0.127 \\
\hline Observations & \multicolumn{3}{|c|}{23122} & \multicolumn{3}{|c|}{22557} & \multicolumn{2}{|c|}{45679} \\
\hline Log likelihood & \multicolumn{3}{|c|}{-8206.28} & \multicolumn{3}{|c|}{-9295.73} & \multicolumn{2}{|c|}{-17595.11} \\
\hline$\chi^{2}(50)$ & \multicolumn{3}{|c|}{1501.60} & \multicolumn{3}{|c|}{1649.63} & \multicolumn{2}{|c|}{3076.01} \\
\hline P-value & \multicolumn{3}{|c|}{0.00} & \multicolumn{3}{|c|}{0.00} & \multicolumn{2}{|c|}{0.00} \\
\hline
\end{tabular}

Notes: Data from the LFS Winter quarter 2002/03. Dependent variable is participation in any education or training in the previous 4 weeks. ${ }^{* * *}, * *$ and $*$ denote significance at the 1 per cent, 5 per cent and 10 per cent level respectively. $\chi^{2}$ statistic is a test of the significance of the regression (degrees of freedom in parentheses); $\mathrm{P}$-value indicates significance level. 
Table 3: Participation in on-the-job education or training in the last 4 weeks

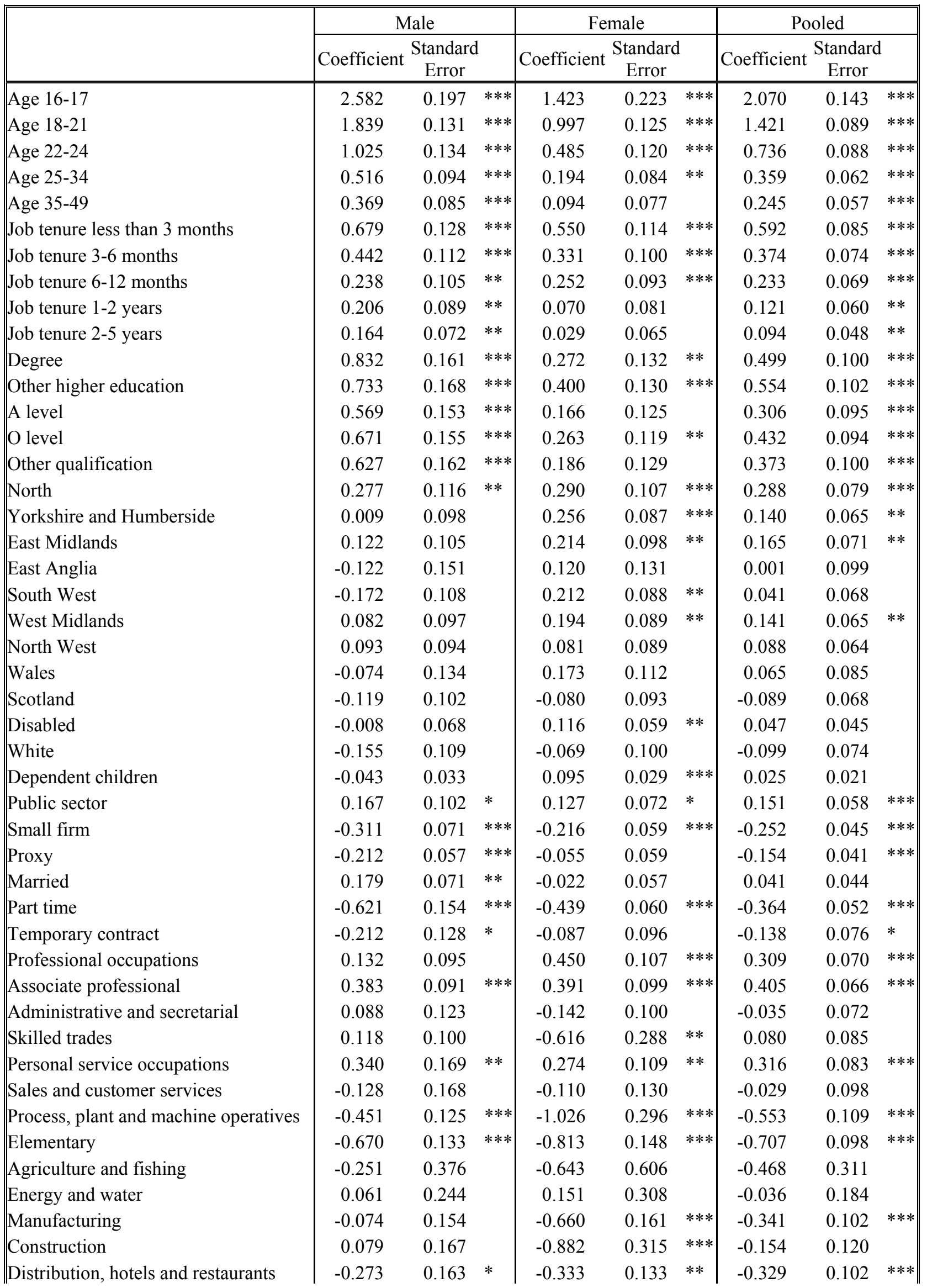




\begin{tabular}{|c|c|c|c|c|c|c|c|c|}
\hline Transport and communication & 0.090 & 0.166 & & -0.272 & 0.169 & -0.109 & 0.113 & \\
\hline Banking and finance & 0.161 & 0.153 & & 0.023 & 0.122 & 0.070 & 0.094 & \\
\hline Public admin, education and health & 0.487 & 0.153 & $* * *$ & 0.136 & 0.112 & 0.324 & 0.090 & $* * *$ \\
\hline Second job & 0.314 & 0.137 & $* *$ & 0.024 & 0.109 & 0.110 & 0.085 & \\
\hline Constant & -3.789 & 0.252 & $* * *$ & -2.783 & $0.210 \quad * * *$ & -3.260 & 0.159 & **** \\
\hline Observations & \multicolumn{3}{|c|}{23119} & \multicolumn{2}{|c|}{22557} & \multicolumn{3}{|c|}{45676} \\
\hline Log likelihood & \multicolumn{3}{|c|}{-5499.59} & \multicolumn{2}{|c|}{-6425.40} & \multicolumn{3}{|c|}{-11996.68} \\
\hline $\operatorname{LR} \chi^{2}(50)$ & \multicolumn{3}{|c|}{907.14} & \multicolumn{2}{|c|}{880.41} & \multicolumn{3}{|c|}{1701.31} \\
\hline P-value & \multicolumn{3}{|c|}{0.00} & \multicolumn{2}{|c|}{0.00} & \multicolumn{3}{|c|}{0.00} \\
\hline
\end{tabular}

Notes: Data from the LFS Winter quarter 2002/03. Dependent variable is participation in on-the-job education or training in the previous 4 weeks. See also notes to Table 2. 
Table 4: Participation in off-the-job education or training in the last 4 weeks

\begin{tabular}{|c|c|c|c|c|c|c|c|c|c|}
\hline & \multicolumn{3}{|c|}{ Male } & \multicolumn{3}{|c|}{ Female } & \multicolumn{3}{|c|}{ Pooled } \\
\hline & Coefficient & $\begin{array}{c}\text { Standard } \\
\text { Error }\end{array}$ & & Coefficient & $\begin{array}{c}\text { Standard } \\
\text { Error } \\
\end{array}$ & & Coefficient & $\begin{array}{c}\text { Standard } \\
\text { Error } \\
\end{array}$ & \\
\hline Age 16-17 & 2.367 & 0.211 & $* * *$ & 1.353 & 0.250 & $* * *$ & 1.960 & 0.157 & $* * *$ \\
\hline Age 18-21 & 1.755 & 0.130 & $* * *$ & 0.698 & 0.132 & $* * *$ & 1.280 & 0.091 & $* * *$ \\
\hline Age $22-24$ & 1.048 & 0.130 & $* * *$ & 0.482 & 0.115 & $* * *$ & 0.774 & 0.086 & $* * *$ \\
\hline Age $25-34$ & 0.666 & 0.089 & $* * *$ & 0.244 & 0.078 & $* * *$ & 0.467 & 0.058 & $* * *$ \\
\hline Age 35-49 & 0.580 & 0.080 & $* * *$ & 0.263 & 0.071 & $* * *$ & 0.436 & 0.052 & $* * *$ \\
\hline Job tenure less than 3 months & -0.087 & 0.150 & & 0.026 & 0.127 & & -0.043 & 0.097 & \\
\hline Job tenure 3-6 months & 0.168 & 0.112 & & 0.068 & 0.102 & & 0.104 & 0.075 & \\
\hline Job tenure $6-12$ months & -0.033 & 0.104 & & 0.291 & 0.087 & $* * *$ & 0.135 & 0.066 & $* *$ \\
\hline Job tenure $1-2$ years & 0.099 & 0.083 & & 0.154 & 0.074 & $* *$ & 0.119 & 0.055 & $* *$ \\
\hline Job tenure $2-5$ years & 0.167 & 0.065 & $* * *$ & 0.073 & 0.059 & & 0.116 & 0.043 & $* * *$ \\
\hline Degree & 1.720 & 0.208 & $* * *$ & 1.084 & 0.145 & $* * *$ & 1.288 & 0.116 & $* * *$ \\
\hline Other higher education & 1.609 & 0.212 & $* * *$ & 1.121 & 0.143 & $* * *$ & 1.301 & 0.117 & $* * *$ \\
\hline A level & 1.284 & 0.203 & $* * *$ & 0.842 & 0.141 & $* * *$ & 0.932 & 0.113 & $* * *$ \\
\hline O level & 1.392 & 0.205 & $* * *$ & 0.665 & 0.137 & $* * *$ & 0.914 & 0.113 & $* * *$ \\
\hline Other qualification & 1.282 & 0.212 & $* * *$ & 0.553 & 0.147 & $* * *$ & 0.816 & 0.119 & $* * *$ \\
\hline North & 0.261 & 0.108 & $* *$ & 0.253 & 0.101 & $* *$ & 0.255 & 0.074 & $* * *$ \\
\hline Yorkshire and Humberside & 0.081 & 0.090 & & 0.132 & 0.083 & & 0.097 & 0.061 & \\
\hline East Midlands & -0.004 & 0.102 & & 0.125 & 0.093 & & 0.063 & 0.068 & \\
\hline East Anglia & -0.260 & 0.146 & $*$ & -0.143 & 0.132 & & -0.206 & 0.098 & $* *$ \\
\hline South West & -0.010 & 0.094 & & 0.116 & 0.083 & & 0.047 & 0.062 & \\
\hline West Midlands & -0.035 & 0.094 & & 0.135 & 0.084 & & 0.053 & 0.062 & \\
\hline North West & -0.026 & 0.090 & & 0.141 & 0.082 & $*$ & 0.060 & 0.060 & \\
\hline Wales & -0.056 & 0.122 & & 0.241 & 0.101 & $* *$ & 0.105 & 0.077 & \\
\hline Scotland & -0.223 & 0.096 & $* *$ & -0.082 & 0.085 & & -0.149 & 0.063 & $* *$ \\
\hline Disabled & 0.177 & 0.062 & $* * *$ & 0.115 & 0.056 & $* *$ & 0.130 & 0.041 & $* * *$ \\
\hline White & -0.001 & 0.107 & & -0.077 & 0.095 & & -0.032 & 0.071 & \\
\hline Dependent children & -0.005 & 0.030 & & 0.045 & 0.027 & & 0.015 & 0.020 & \\
\hline Public sector & 0.423 & 0.093 & $* * *$ & 0.252 & 0.066 & $* * *$ & 0.305 & 0.054 & $* * *$ \\
\hline Small firm & -0.124 & 0.064 & $*$ & 0.094 & 0.054 & $*$ & 0.006 & 0.041 & \\
\hline Proxy & -0.189 & 0.054 & $* * *$ & -0.213 & 0.058 & $* * *$ & -0.213 & 0.039 & $* * *$ \\
\hline Married & 0.026 & 0.065 & & -0.001 & 0.053 & & -0.014 & 0.041 & \\
\hline Part time & -0.074 & 0.132 & & -0.241 & 0.055 & $* * *$ & -0.119 & 0.047 & $* *$ \\
\hline Temporary & -0.221 & 0.127 & $*$ & -0.018 & 0.088 & & -0.078 & 0.072 & \\
\hline Professional occupations & 0.012 & 0.081 & & 0.170 & 0.091 & $*$ & 0.102 & 0.060 & $*$ \\
\hline Associate professional & 0.090 & 0.080 & & 0.081 & 0.086 & & 0.096 & 0.058 & $*$ \\
\hline Administrative and secretarial & -0.281 & 0.116 & $* *$ & -0.405 & 0.087 & $* * *$ & -0.348 & 0.065 & $* * *$ \\
\hline Skilled trades & -0.181 & 0.090 & $* *$ & -1.087 & 0.294 & $* * *$ & -0.240 & 0.078 & $* * *$ \\
\hline Personal service occupations & -0.278 & 0.178 & & -0.055 & 0.096 & & -0.047 & 0.075 & \\
\hline Sales and customer services & -0.825 & 0.187 & $* * *$ & -0.854 & 0.135 & $* * *$ & -0.790 & 0.105 & $* * *$ \\
\hline Process, plant and machine operatives & -0.910 & 0.125 & $* * *$ & -0.799 & 0.246 & $* * *$ & -0.889 & 0.108 & $* * *$ \\
\hline Elementary & -1.159 & 0.136 & $* * *$ & -1.207 & 0.146 & $* * *$ & -1.149 & 0.099 & $* * *$ \\
\hline Agriculture and fishing & -0.161 & 0.340 & & 0.020 & 0.482 & & -0.158 & 0.273 & \\
\hline Energy and water & 0.371 & 0.204 & $*$ & 0.386 & 0.302 & & 0.335 & 0.161 & $* *$ \\
\hline Manufacturing & -0.143 & 0.139 & & -0.286 & 0.152 & $*$ & -0.189 & 0.097 & $*$ \\
\hline Construction & 0.359 & 0.147 & $* *$ & 0.140 & 0.224 & & 0.335 & 0.108 & $* * *$ \\
\hline Distribution, hotels and restaurants & -0.321 & 0.148 & $* *$ & -0.075 & 0.133 & & -0.202 & 0.098 & $* *$ \\
\hline
\end{tabular}




\begin{tabular}{|c|c|c|c|c|c|c|c|c|c|}
\hline Transport and communication & -0.078 & 0.155 & & -0.173 & 0.172 & & -0.108 & 0.111 & \\
\hline Banking and finance & 0.085 & 0.137 & & 0.038 & 0.122 & & 0.070 & 0.090 & \\
\hline Public admin, education and health & 0.171 & 0.137 & & 0.395 & 0.110 & $* * *$ & 0.376 & 0.085 & $* * *$ \\
\hline Second job & 0.353 & 0.123 & $* * *$ & 0.324 & 0.091 & $* * *$ & 0.320 & 0.073 & $* * *$ \\
\hline Constant & -4.290 & 0.274 & $* * *$ & -3.277 & 0.213 & $* * *$ & -3.718 & 0.164 & $* * *$ \\
\hline Observations & \multicolumn{3}{|c|}{23119} & \multicolumn{3}{|c|}{22557} & \multicolumn{3}{|c|}{45676} \\
\hline Log likelihood & \multicolumn{3}{|c|}{-6081.63} & \multicolumn{3}{|c|}{-7034.78} & \multicolumn{3}{|c|}{-13191.22} \\
\hline $\operatorname{LR} \chi^{2}(50)$ & \multicolumn{3}{|c|}{1120.64} & \multicolumn{3}{|c|}{1347.55} & \multicolumn{3}{|c|}{2396.12} \\
\hline P-value & \multicolumn{3}{|c|}{0.00} & \multicolumn{3}{|c|}{0.00} & \multicolumn{3}{|c|}{0.00} \\
\hline
\end{tabular}

Notes: Dependent variable is participation in off-the-job education or training in the previous 4 weeks. See also notes to Table 2. 
Table 5: Participation in employer-funded off-the-job training in the last 4 weeks

\begin{tabular}{|c|c|c|c|c|c|c|c|c|c|}
\hline & \multicolumn{3}{|c|}{ Male } & \multicolumn{3}{|c|}{ Female } & \multicolumn{3}{|c|}{ Pooled } \\
\hline & Coefficient & $\begin{array}{l}\text { Standard } \\
\text { Error }\end{array}$ & & Coefficient & $\begin{array}{c}\text { Standard } \\
\text { Error }\end{array}$ & & Coefficient & $\begin{array}{c}\text { Standard } \\
\text { Error }\end{array}$ & \\
\hline Age 16-17 & 2.459 & 0.245 & $* * *$ & 1.443 & 0.321 & $* * *$ & 2.112 & 0.187 & $* * *$ \\
\hline Age $18-21$ & 1.757 & 0.154 & $* * *$ & 0.706 & 0.166 & $* * *$ & 1.315 & 0.110 & $* * *$ \\
\hline Age $22-24$ & 0.978 & 0.155 & $* * *$ & 0.401 & 0.143 & $* * *$ & 0.719 & 0.104 & $* * *$ \\
\hline Age $25-34$ & 0.585 & 0.103 & $* * *$ & 0.130 & 0.095 & & 0.389 & 0.069 & $* * *$ \\
\hline Age $35-49$ & 0.529 & 0.092 & $* * *$ & 0.213 & 0.085 & $* *$ & 0.402 & 0.062 & $* * *$ \\
\hline Job tenure less than 3 months & -0.145 & 0.185 & & -0.118 & 0.170 & & -0.155 & 0.125 & \\
\hline Job tenure $3-6$ months & 0.169 & 0.132 & & -0.005 & 0.129 & & 0.067 & 0.092 & \\
\hline Job tenure $6-12$ months & -0.039 & 0.123 & & 0.250 & 0.109 & $* *$ & 0.099 & 0.081 & \\
\hline Job tenure $1-2$ years & 0.035 & 0.098 & & 0.205 & 0.089 & $* *$ & 0.115 & 0.066 & * \\
\hline Job tenure $2-5$ years & 0.111 & 0.075 & & 0.096 & 0.071 & & 0.107 & 0.051 & $* *$ \\
\hline Degree & 1.573 & 0.241 & $* * *$ & 0.968 & 0.186 & $* * *$ & 1.196 & 0.145 & $* * *$ \\
\hline Other higher education & 1.476 & 0.245 & $* * *$ & 0.983 & 0.184 & $* * *$ & 1.205 & 0.146 & $* * *$ \\
\hline A level & 1.114 & 0.236 & $* * *$ & 0.750 & 0.183 & $* * *$ & 0.836 & 0.142 & $* * *$ \\
\hline O level & 1.204 & 0.239 & $* * *$ & 0.542 & 0.179 & $* * *$ & 0.812 & 0.143 & $* * *$ \\
\hline Other qualification & 1.126 & 0.247 & $* * *$ & 0.425 & 0.193 & $* *$ & 0.729 & 0.151 & $* * *$ \\
\hline North & 0.262 & 0.126 & $* *$ & 0.260 & 0.121 & $* *$ & 0.259 & 0.087 & $* * *$ \\
\hline Yorkshire and Humberside & 0.089 & 0.105 & & 0.200 & 0.099 & $* *$ & 0.135 & 0.072 & $*$ \\
\hline East Midlands & 0.047 & 0.117 & & 0.132 & 0.113 & & 0.087 & 0.081 & \\
\hline East Anglia & -0.261 & 0.172 & & -0.189 & 0.165 & & -0.234 & 0.119 & $* *$ \\
\hline South West & 0.003 & 0.110 & & 0.202 & 0.099 & $* *$ & 0.096 & 0.073 & \\
\hline West Midlands & 0.066 & 0.106 & & 0.161 & 0.101 & & 0.109 & 0.073 & \\
\hline North West & -0.049 & 0.106 & & 0.169 & 0.097 & $*$ & 0.062 & 0.072 & \\
\hline Wales & -0.132 & 0.147 & & 0.135 & 0.125 & & 0.011 & 0.095 & \\
\hline Scotland & -0.142 & 0.110 & & -0.137 & 0.104 & & -0.143 & 0.075 & $*$ \\
\hline Disabled & 0.143 & 0.072 & $* *$ & 0.075 & 0.068 & & 0.090 & 0.049 & $*$ \\
\hline White & 0.048 & 0.129 & & 0.238 & 0.127 & $*$ & 0.158 & 0.090 & $*$ \\
\hline Dependent children & 0.012 & 0.034 & & 0.083 & 0.033 & $* *$ & 0.040 & 0.023 & $*$ \\
\hline Public sector & 0.379 & 0.109 & $* * *$ & 0.418 & 0.082 & $* * *$ & 0.402 & 0.065 & $* * *$ \\
\hline Small firm & -0.181 & 0.076 & $* *$ & -0.005 & 0.067 & & -0.077 & 0.050 & \\
\hline Proxy & -0.097 & 0.062 & & -0.118 & 0.068 & $*$ & -0.121 & 0.045 & $* * *$ \\
\hline Married & 0.066 & 0.077 & & 0.130 & 0.064 & $* *$ & 0.080 & 0.049 & \\
\hline Part-time & -0.480 & 0.190 & $* *$ & -0.412 & 0.068 & $* * *$ & -0.295 & 0.060 & $* * *$ \\
\hline Temporary contract & -0.476 & 0.169 & $* * *$ & -0.249 & 0.114 & $* *$ & -0.323 & 0.094 & $* * *$ \\
\hline Professional occupations & -0.031 & 0.091 & & 0.055 & 0.105 & & 0.032 & 0.068 & \\
\hline Associate professional & 0.069 & 0.091 & & 0.018 & 0.099 & & 0.056 & 0.066 & \\
\hline Administrative and secretarial & -0.499 & 0.141 & $* * *$ & -0.525 & 0.103 & $* * *$ & -0.469 & 0.077 & $* * *$ \\
\hline Skilled trades & -0.282 & 0.104 & $* * *$ & -1.030 & 0.351 & $* * *$ & -0.308 & 0.090 & $* * *$ \\
\hline Personal service occupations & -0.279 & 0.205 & & -0.298 & 0.115 & $* * *$ & -0.250 & 0.091 & $* * *$ \\
\hline Sales and customer services & -1.287 & 0.269 & $* * *$ & -1.008 & 0.177 & $* * *$ & -1.058 & 0.142 & $* * *$ \\
\hline Process, plant and machine operatives & -1.161 & 0.153 & $* * *$ & -1.634 & 0.401 & $* * *$ & -1.216 & 0.138 & $* * *$ \\
\hline Elementary & -1.722 & 0.193 & $* * *$ & -2.147 & 0.252 & $* * *$ & -1.861 & 0.152 & $* * *$ \\
\hline Agriculture and fishing & 0.084 & 0.379 & & -0.291 & 0.737 & & 0.022 & 0.328 & \\
\hline Energy and water & 0.471 & 0.232 & $* *$ & 0.522 & 0.365 & & 0.499 & 0.186 & $* * *$ \\
\hline Manufacturing & -0.105 & 0.165 & & -0.105 & 0.189 & & -0.072 & 0.119 & \\
\hline Construction & 0.403 & 0.173 & $* *$ & 0.105 & 0.287 & & 0.427 & 0.130 & $* * *$ \\
\hline Distribution, hotels and restaurants & -0.394 & 0.180 & $* *$ & -0.217 & 0.177 & & -0.289 & 0.125 & $* *$ \\
\hline
\end{tabular}




\begin{tabular}{|c|c|c|c|c|c|c|c|c|c|}
\hline Transport and communication & -0.005 & 0.184 & & 0.098 & 0.209 & & 0.063 & 0.135 & \\
\hline Banking and finance & 0.061 & 0.163 & & 0.212 & 0.154 & & 0.162 & 0.112 & \\
\hline Public admin, education and health & 0.216 & 0.162 & & 0.422 & 0.142 & *** & 0.402 & 0.105 & *** \\
\hline Second job & 0.266 & 0.148 & * & 0.212 & 0.116 & * & 0.206 & 0.091 & $* *$ \\
\hline Constant & -4.450 & 0.320 & **** & -3.914 & 0.274 & $* * *$ & -4.209 & 0.205 & $* * *$ \\
\hline Observations & \multirow{3}{*}{\multicolumn{3}{|c|}{$\begin{array}{c}23019 \\
-4746.27 \\
922.78\end{array}$}} & \multicolumn{3}{|c|}{22415} & \multicolumn{3}{|c|}{45434} \\
\hline Log likelihood & & & & & 49.93 & & & 50.96 & \\
\hline $\operatorname{LR} \chi^{2}(50)$ & & & & \multicolumn{3}{|c|}{1173.71} & \multicolumn{3}{|c|}{2010.16} \\
\hline P-value & \multicolumn{3}{|c|}{0.00} & \multicolumn{3}{|c|}{0.00} & \multicolumn{3}{|c|}{0.00} \\
\hline
\end{tabular}

Notes: Dependent variable is participation in off-the-job education or training in the previous 4 weeks either wholly or partly funded by the employer. See also notes to Table 2. 
Table 6: Participation in any employer-funded job training in the last 4 weeks

\begin{tabular}{|c|c|c|c|c|c|c|c|c|c|}
\hline & \multicolumn{3}{|c|}{ Male } & \multicolumn{3}{|c|}{ Female } & \multicolumn{3}{|c|}{ Pooled } \\
\hline & Coefficient & $\begin{array}{c}\text { Standard } \\
\text { Error }\end{array}$ & & Coefficient & $\begin{array}{c}\text { Standard } \\
\text { Error }\end{array}$ & & Coefficient & $\begin{array}{c}\text { Standard } \\
\text { Error }\end{array}$ & \\
\hline Age 16-17 & 2.565 & 0.182 & $* * *$ & 1.359 & 0.212 & $* * *$ & 2.061 & 0.134 & $* * *$ \\
\hline Age 18-21 & 1.779 & 0.113 & $* * *$ & 0.907 & 0.112 & $* * *$ & 1.370 & 0.078 & $* * *$ \\
\hline Age 22-24 & 0.957 & 0.114 & $* * *$ & 0.445 & 0.104 & $* * *$ & 0.707 & 0.076 & $* * *$ \\
\hline Age 25-34 & 0.517 & 0.076 & $* * *$ & 0.129 & 0.070 & $*$ & 0.340 & 0.051 & $* * *$ \\
\hline Age 35-49 & 0.428 & 0.068 & $* * *$ & 0.130 & 0.064 & $* *$ & 0.303 & 0.046 & $* * *$ \\
\hline Job tenure less than 3 months & 0.467 & 0.115 & $* * *$ & 0.375 & 0.105 & $* * *$ & 0.398 & 0.077 & $* * *$ \\
\hline Job tenure 3-6 months & 0.300 & 0.098 & $* * *$ & 0.218 & 0.090 & $* *$ & 0.248 & 0.066 & $* * *$ \\
\hline Job tenure 6-12 months & 0.165 & 0.088 & $*$ & 0.291 & 0.080 & $* * *$ & 0.218 & 0.059 & $* * *$ \\
\hline Job tenure $1-2$ years & 0.096 & 0.075 & & 0.156 & 0.068 & $* *$ & 0.118 & 0.050 & $* *$ \\
\hline Job tenure $2-5$ years & 0.123 & 0.058 & $* *$ & 0.074 & 0.054 & & 0.100 & 0.039 & $* *$ \\
\hline Degree & 1.120 & 0.142 & $* * *$ & 0.621 & 0.117 & $* * *$ & 0.816 & 0.089 & $* * *$ \\
\hline Other higher education & 1.027 & 0.147 & $* * *$ & 0.681 & 0.116 & $* * *$ & 0.840 & 0.090 & $* * *$ \\
\hline A level & 0.775 & 0.136 & $* * *$ & 0.438 & 0.112 & $* * *$ & 0.540 & 0.085 & $* * *$ \\
\hline O level & 0.841 & 0.139 & $* * *$ & 0.419 & 0.108 & $* * *$ & 0.589 & 0.085 & $* * *$ \\
\hline Other qualification & 0.760 & 0.145 & $* * *$ & 0.361 & 0.116 & $* * *$ & 0.530 & 0.090 & $* * *$ \\
\hline North & 0.283 & 0.097 & $* * *$ & 0.235 & 0.092 & $* *$ & 0.259 & 0.067 & $* * *$ \\
\hline Yorkshire and Humberside & 0.089 & 0.080 & & 0.244 & 0.074 & $* * *$ & 0.165 & 0.054 & $* * *$ \\
\hline East Midlands & 0.102 & 0.087 & & 0.187 & 0.083 & $* *$ & 0.141 & 0.060 & $* *$ \\
\hline East Anglia & -0.115 & 0.123 & & -0.006 & 0.114 & & -0.068 & 0.083 & \\
\hline South West & -0.127 & 0.087 & & 0.192 & 0.075 & $* *$ & 0.041 & 0.056 & \\
\hline West Midlands & 0.078 & 0.081 & & 0.222 & 0.075 & $* * *$ & 0.151 & 0.055 & $* * *$ \\
\hline North West & 0.025 & 0.079 & & 0.100 & 0.074 & & 0.065 & 0.054 & \\
\hline Wales & -0.123 & 0.111 & & 0.209 & 0.094 & $* *$ & 0.060 & 0.071 & \\
\hline Scotland & -0.167 & 0.084 & $* *$ & -0.114 & 0.078 & & -0.136 & 0.057 & $* *$ \\
\hline Disabled & 0.060 & 0.055 & & 0.112 & 0.050 & $* *$ & 0.073 & 0.037 & $* *$ \\
\hline White & -0.004 & 0.095 & & 0.058 & 0.089 & & 0.041 & 0.065 & \\
\hline Dependent children & -0.004 & 0.026 & & 0.097 & 0.025 & $* * *$ & 0.038 & 0.018 & $* *$ \\
\hline Public sector & 0.241 & 0.083 & $* * *$ & 0.310 & 0.061 & $* * *$ & 0.288 & 0.049 & $* * *$ \\
\hline Small firm & -0.300 & 0.058 & $* * *$ & -0.139 & 0.050 & $* * *$ & -0.203 & 0.038 & $* * *$ \\
\hline Proxy & -0.222 & 0.047 & $* * *$ & -0.057 & 0.050 & & -0.161 & 0.034 & $* * *$ \\
\hline Married & 0.122 & 0.058 & $* *$ & 0.055 & 0.048 & & 0.066 & 0.037 & $*$ \\
\hline Part-time & -0.570 & 0.130 & $* * *$ & -0.438 & 0.050 & $* * *$ & -0.350 & 0.043 & $* * *$ \\
\hline Temporary & -0.307 & 0.113 & $* * *$ & -0.222 & 0.084 & $* * *$ & -0.255 & 0.067 & $* * *$ \\
\hline Professional occupations & 0.075 & 0.074 & & 0.324 & 0.086 & $* * *$ & 0.214 & 0.055 & $* * *$ \\
\hline Associate professional & 0.257 & 0.072 & $* * *$ & 0.235 & 0.080 & $* * *$ & 0.257 & 0.053 & $* * *$ \\
\hline Administrative and secretarial & -0.135 & 0.102 & & -0.280 & 0.080 & $* * *$ & -0.196 & 0.058 & $* * *$ \\
\hline Skilled trades & -0.106 & 0.080 & & -0.778 & 0.237 & $* * *$ & -0.137 & 0.069 & $* *$ \\
\hline Personal service occupations & 0.067 & 0.146 & & 0.042 & 0.089 & & 0.085 & 0.069 & \\
\hline Sales and customer services & -0.534 & 0.153 & $* * *$ & -0.398 & 0.111 & $* * *$ & -0.360 & 0.085 & $* * *$ \\
\hline Process, plant and machine operatives & -0.721 & 0.104 & $* * *$ & -1.168 & 0.248 & $* * *$ & -0.800 & 0.091 & $* * *$ \\
\hline Elementary & -1.015 & 0.115 & $* * *$ & -1.222 & 0.131 & $* * *$ & -1.078 & 0.086 & $* * *$ \\
\hline Agriculture and fishing & -0.045 & 0.291 & & -0.586 & 0.530 & & -0.230 & 0.247 & \\
\hline Energy and water & 0.324 & 0.185 & $*$ & 0.440 & 0.260 & $*$ & 0.293 & 0.144 & $* *$ \\
\hline Manufacturing & -0.109 & 0.126 & & -0.478 & 0.137 & $* * *$ & -0.240 & 0.086 & $* * *$ \\
\hline Construction & 0.229 & 0.135 & $*$ & -0.474 & 0.234 & $* *$ & 0.099 & 0.099 & \\
\hline Distribution, hotels and restaurants & -0.314 & 0.134 & $* *$ & -0.218 & 0.117 & $*$ & -0.268 & 0.087 & $* * *$ \\
\hline
\end{tabular}




\begin{tabular}{|c|c|c|c|c|c|c|c|c|}
\hline Transport and communication & 0.030 & 0.137 & & -0.112 & 0.146 & & -0.041 & 0.096 \\
\hline Banking and finance & 0.111 & 0.125 & & 0.099 & 0.107 & & 0.110 & 0.081 \\
\hline Public admin, education and health & 0.409 & 0.125 & **** & 0.271 & 0.098 & $* * *$ & 0.385 & 0.077 \\
\hline Second job & 0.335 & 0.114 & $* * *$ & 0.135 & 0.090 & & 0.184 & 0.070 \\
\hline Constant & -3.433 & 0.214 & **** & -2.728 & 0.184 & **** & -3.096 & 0.138 \\
\hline Observations & \multicolumn{3}{|c|}{23052} & \multicolumn{3}{|c|}{22458} & \multicolumn{2}{|c|}{45510} \\
\hline Log likelihood & \multicolumn{3}{|c|}{-7407.44} & \multicolumn{3}{|c|}{-8274.22} & \multicolumn{2}{|c|}{-15768.67} \\
\hline $\operatorname{LR} \chi^{2}(50)$ & \multicolumn{3}{|c|}{1374.14} & \multicolumn{3}{|c|}{1560.41} & \multicolumn{2}{|c|}{2835.00} \\
\hline P-value & \multicolumn{3}{|c|}{0.00} & \multicolumn{3}{|c|}{0.00} & \multicolumn{2}{|c|}{0.00} \\
\hline
\end{tabular}

Notes: Dependent variable is participation in on-the-job education or training in the previous 4 weeks or off-thejob education or training either wholly or partly funded by the employer. See also notes to Table 2. 
Table 7: Logit decomposition of gender training gap

\begin{tabular}{|c|c|c|c|c|c|}
\hline & Any training & On-the-job & Off-the-job & $\begin{array}{c}\text { Off the job } \\
\text { with employer } \\
\text { contribution }\end{array}$ & $\begin{array}{c}\text { Any with } \\
\text { employer } \\
\text { contribution }\end{array}$ \\
\hline $\begin{array}{l}\text { Difference in } \\
\text { mean predicted } \\
\text { training } \\
\text { incidence }\end{array}$ & 0.035 & 0.019 & 0.024 & 0.011 & 0.027 \\
\hline \multirow{2}{*}{$\begin{array}{l}\text { Difference due } \\
\text { to coefficients }\end{array}$} & 0.010 & 0.006 & 0.009 & 0.006 & 0.010 \\
\hline & $(30 \%)$ & $(32 \%)$ & $(36 \%)$ & $(56 \%)$ & $(63 \%)$ \\
\hline \multirow{2}{*}{$\begin{array}{l}\text { Difference due } \\
\text { to characteristics }\end{array}$} & 0.025 & 0.0132 & 0.015 & 0.005 & 0.017 \\
\hline & $(71 \%)$ & $(68 \%)$ & $(64 \%)$ & $(44 \%)$ & $(37 \%)$ \\
\hline \multicolumn{6}{|l|}{$\begin{array}{l}\text { Breakdown of } \\
\text { characteristics } \\
\text { effect }(\%)\end{array}$} \\
\hline Age & 4 & 2 & 8 & 33 & 4 \\
\hline Tenure & 4 & 6 & 3 & 11 & 6 \\
\hline Qualifications & -3 & 7 & -11 & -53 & -2 \\
\hline Region & 0 & 1 & 0 & -1 & -1 \\
\hline Disability & -1 & 0 & -1 & -4 & -1 \\
\hline Ethnicity & 0 & 0 & 0 & 3 & 0 \\
\hline $\begin{array}{l}\text { Dependent } \\
\text { children }\end{array}$ & 1 & 1 & 0 & 6 & 1 \\
\hline Public sector & 26 & 17 & 35 & 240 & 39 \\
\hline Small firm & -4 & -8 & 0 & -12 & -8 \\
\hline Proxy interview & 17 & 15 & 22 & 64 & 19 \\
\hline Marriage & 0 & 0 & 0 & -3 & -1 \\
\hline Part time & -43 & -79 & -27 & -342 & -93 \\
\hline Temporary & -2 & -2 & -1 & -20 & -4 \\
\hline Occupation & 29 & 47 & 2 & -39 & 42 \\
\hline Industry & 69 & 94 & 64 & 201 & 92 \\
\hline Second job & 3 & 2 & 5 & 16 & 3 \\
\hline
\end{tabular}

Notes: Decompositions based on results in Tables 2-6 and refer to the Winter quarter 2002/03. Predicted (actual) training gap is defined as: $\overline{\mathrm{P}}\left(\mathrm{X}_{\mathrm{i}}^{\mathrm{F}} \hat{\beta}^{\mathrm{F}}\right)-\overline{\mathrm{P}}\left(\mathrm{X}_{\mathrm{i}}^{\mathrm{M}} \hat{\beta}^{\mathrm{M}}\right)$. The characteristics contribution is defined using the pooled coefficients as the baseline structure as $\bar{P}\left(X_{i}^{\mathrm{F}} \hat{\beta}^{*}\right)-\overline{\mathrm{P}}\left(\mathrm{X}_{\mathrm{i}}^{\mathrm{M}} \hat{\beta}^{*}\right)$; the corresponding coefficients contribution is defined as $\left[\overline{\mathrm{P}}\left(\mathrm{X}_{\mathrm{i}}^{\mathrm{F}} \hat{\beta}^{\mathrm{F}}\right)-\overline{\mathrm{P}}\left(\mathrm{X}_{\mathrm{i}}^{\mathrm{F}} \hat{\beta}^{*}\right)\right]+\left[\overline{\mathrm{P}}\left(\mathrm{X}_{\mathrm{i}}^{\mathrm{M}} \hat{\beta}^{*}\right)-\overline{\mathrm{P}}\left(\mathrm{X}_{\mathrm{i}}^{\mathrm{M}} \hat{\beta}^{\mathrm{M}}\right)\right]$. The detailed characteristics breakdown is based on the method of Even and Macpherson (1990, 1993); see text for details. A full breakdown of grouped variables is available on request. 
Table 8: Logit decompositions 1995-2001

(a) Gender decomposition - 1995

\begin{tabular}{|c|c|c|c|c|c|}
\hline & Any training & On the job & Off the job & $\begin{array}{c}\text { Off the job } \\
\text { with employer } \\
\text { contribution }\end{array}$ & $\begin{array}{c}\text { Any with } \\
\text { employer } \\
\text { contribution }\end{array}$ \\
\hline $\begin{array}{l}\text { Difference in mean } \\
\text { predicted training } \\
\text { incidence }\end{array}$ & 0.0127 & 0.0009 & 0.0115 & -0.0010 & 0.0012 \\
\hline $\begin{array}{l}\text { Difference due to } \\
\text { characteristics }\end{array}$ & $\begin{array}{l}0.0114 \\
(90 \%)\end{array}$ & $\begin{array}{l}0.0035 \\
(397 \%)\end{array}$ & $\begin{array}{l}0.0078 \\
(68 \%)\end{array}$ & $\begin{array}{l}-0.0023 \\
(232 \%)\end{array}$ & $\begin{array}{l}0.0021 \\
(179 \%)\end{array}$ \\
\hline $\begin{array}{l}\text { Difference due to } \\
\text { coefficients }\end{array}$ & $\begin{array}{l}0.0013 \\
(10 \%)\end{array}$ & $\begin{array}{l}-0.0026 \\
(-297 \%)\end{array}$ & $\begin{array}{l}0.0037 \\
(32 \%)\end{array}$ & $\begin{array}{c}0.0013 \\
(-132 \%)\end{array}$ & $\begin{array}{l}-0.0009 \\
(-79 \%)\end{array}$ \\
\hline
\end{tabular}

(b) Gender decomposition - 2001

\begin{tabular}{|c|c|c|c|c|c|}
\hline & Any training & On the job & Off the job & $\begin{array}{c}\text { Off the job } \\
\text { with employer } \\
\text { contribution }\end{array}$ & $\begin{array}{c}\text { Any with } \\
\text { employer } \\
\text { contribution }\end{array}$ \\
\hline $\begin{array}{l}\text { Difference in mean } \\
\text { predicted training } \\
\text { incidence }\end{array}$ & 0.0282 & 0.0102 & 0.0237 & 0.0109 & 0.0170 \\
\hline $\begin{array}{l}\text { Difference due to } \\
\text { characteristics }\end{array}$ & $\begin{array}{l}0.0193 \\
(69 \%) \\
\end{array}$ & $\begin{array}{l}0.0080 \\
(79 \%) \\
\end{array}$ & $\begin{array}{l}0.0135 \\
(57 \%) \\
\end{array}$ & $\begin{array}{l}0.0032 \\
(29 \%)\end{array}$ & $\begin{array}{l}0.0104 \\
(61 \%)\end{array}$ \\
\hline $\begin{array}{l}\text { Difference due to } \\
\text { coefficients }\end{array}$ & $\begin{array}{l}0.0089 \\
(31 \%)\end{array}$ & $\begin{array}{l}0.0022 \\
(21 \%)\end{array}$ & $\begin{array}{l}0.0102 \\
(43 \%)\end{array}$ & $\begin{array}{c}0.0077 \\
(71 \%)\end{array}$ & $\begin{array}{l}0.0066 \\
(38 \%)\end{array}$ \\
\hline
\end{tabular}

(c) Time-wise decomposition - males 1995-2001

\begin{tabular}{|c|c|c|c|c|c|}
\hline & Any training & On the job & Off the job & $\begin{array}{l}\text { Off the job } \\
\text { with employer } \\
\text { contribution }\end{array}$ & $\begin{array}{c}\text { Any with } \\
\text { employer } \\
\text { contribution }\end{array}$ \\
\hline $\begin{array}{l}\text { Change in mean } \\
\text { predicted training } \\
\text { incidence }\end{array}$ & 0.0189 & 0.0212 & "0.0041 & -0.0019 & 0.0159 \\
\hline $\begin{array}{l}\text { Change due to } \\
\text { characteristics }\end{array}$ & $\begin{array}{c}0.0007 \\
(4 \%)\end{array}$ & $\begin{array}{c}0.0005 \\
(2 \%)\end{array}$ & $\begin{array}{l}0.0006 \\
(15 \%)\end{array}$ & $\begin{array}{c}-0.0008 \\
(42 \%)\end{array}$ & $\begin{array}{c}-0.0004 \\
(-3 \%)\end{array}$ \\
\hline $\begin{array}{l}\text { Change due to } \\
\text { coefficients }\end{array}$ & $\begin{array}{l}0.0182 \\
(96 \%)\end{array}$ & $\begin{array}{l}0.0207 \\
(98 \%)\end{array}$ & $\begin{array}{l}0.0035 \\
(85 \%)\end{array}$ & $\begin{array}{c}-0.0011 \\
(58 \%)\end{array}$ & $\begin{array}{l}0.0163 \\
(103 \%)\end{array}$ \\
\hline
\end{tabular}

\section{(d) Time-wise decomposition - females 1995-2001}

\begin{tabular}{|c|c|c|c|c|c|}
\hline & Any training & On the job & Off the job & $\begin{array}{c}\text { Off the job } \\
\text { with employer } \\
\text { contribution }\end{array}$ & $\begin{array}{c}\text { Any with } \\
\text { employer } \\
\text { contribution }\end{array}$ \\
\hline $\begin{array}{l}\text { Change in mean } \\
\text { predicted training } \\
\text { incidence }\end{array}$ & 0.0344 & 0.0305 & 0.0163 & 0.0100 & 0.0317 \\
\hline $\begin{array}{l}\text { Change due to } \\
\text { characteristics }\end{array}$ & $\begin{array}{l}0.0114 \\
(33 \%)\end{array}$ & $\begin{array}{l}0.0051 \\
(17 \%)\end{array}$ & $\begin{array}{l}0.0079 \\
(48 \%)\end{array}$ & $\begin{array}{l}0.0055 \\
(55 \%)\end{array}$ & $\begin{array}{l}0.0095 \\
(30 \%)\end{array}$ \\
\hline $\begin{array}{l}\text { Change due to } \\
\text { coefficients }\end{array}$ & $\begin{array}{l}0.0230 \\
(67 \%)\end{array}$ & $\begin{array}{l}0.0254 \\
(83 \%)\end{array}$ & $\begin{array}{l}0.0085 \\
(52 \%)\end{array}$ & $\begin{array}{l}0.0045 \\
(45 \%)\end{array}$ & $\begin{array}{l}0.0222 \\
(70 \%)\end{array}$ \\
\hline
\end{tabular}


(e) Any training

\begin{tabular}{||l|c|c|c|c||}
\hline $\begin{array}{l}\text { Breakdown of } \\
\text { characteristics effect } \\
(\%)\end{array}$ & $\begin{array}{c}\text { Gender difference } \\
1995\end{array}$ & $\begin{array}{c}\text { Gender difference } \\
2001\end{array}$ & $\begin{array}{c}\text { Time-wise change } \\
- \text { males } \\
1995-2001\end{array}$ & $\begin{array}{c}\text { Time-wise change } \\
\text { females } \\
1995-2001\end{array}$ \\
\hline \hline Age & 21 & 7 & -222 & -9 \\
\hline Tenure & 27 & 7 & 49 & 4 \\
\hline Qualifications & -70 & -26 & 235 & 03 \\
\hline Regions & -1 & -1 & -3 & -1 \\
\hline Ethnicity & 0 & 0 & -0 & 1 \\
\hline Dependent children & 0 & 0 & -36 & 2 \\
\hline Public sector & 51 & 26 & 1 & -1 \\
\hline Small firm & -25 & -11 & -11 & 0 \\
\hline Proxy interview & 73 & 28 & -11 & -1 \\
\hline Marriage & 0 & 0 & -23 & 0 \\
\hline Part time & -158 & -72 & 1 & 30 \\
\hline Temporary & 1 & -1 & 70 & 11 \\
\hline Occupation & 51 & 19 & 56 & -1 \\
\hline Industry & 121 & 118 & -8 & \\
\hline Second job & 8 & 5 & & \\
\hline
\end{tabular}

Notes: All decompositions are calculated using the relevant pooled coefficients as the baseline (see notes to Table 7 and text). 